\title{
Omaehtoisen muistamisen materiaalisuus ja monimediaisuus
}

Muistitietotutkimus ja uusmaterialismi

\author{
Ulla Savolainen, Karina Lukin ja Anne Heimo
}

$\mathrm{M}$ uistitietotutkimus tarkastelee muistamista ja historiantuottamista omaehtoisena ja usein myös omakohtaisena menneisyyden ja nykyisyyden välisen suhteen pohtimisena. Muistamista ei nähdä ainoastaan menneisyyden hahmottamisena, vaan olennaista on sen analysointi nykyhetkeen ankkuroituvana ja tulevaisuusorientoituneena toimintana. Muistitietotutkimus on ollut suomalaisen folkloristiikan ja etnologian keskeisiä alueita 1990-luvulta lähtien. Suomalaisen muistitietotutkimuksen erityispiirteitä ovat monipuolisten tutkimusaineistojen - sekä haastatteluissa tuotettujen että kirjoitettujen - käyttö sekä metodologinen painotus. (Ks. esim. Peltonen 1996; Ukkonen 2000; Fingerroos, Haanpää, Heimo ja Peltonen 2006; Heimo 2016.) Huomio on kohdistunut pääasiassa kielen avulla välittyneisiin, etenkin kerronnallisiin aineistoihin. Myös metodologinen keskustelu painottui pitkään muistelun suulliseen, kirjalliseen ja kerronnalliseen muotoon paikantuviin kysymyksiin.

Omaehtoinen (vernacular) muistaminen ei kuitenkaan rajoitu ainoastaan verbaalisiin ja kerronnallisiin ilmaisumuotoihin. Menneisyyden ja nykyisyyden välistä suhdetta jäsennetään, reflektoidaan ja luodaan myös muiden välineiden (medioiden) kautta, suhteessa niihin ja niiden ohjaamalla tavalla. (Esim. Peltonen 2003; Lukin 2010; Savolainen 2015; 2018; Kuusisto-Arponen ja Savolainen 2016; Heimo 2017; Korjonen-Kuusipuro ja Kuusisto-Arponen 2017; Koskinen-Koivisto ja Thomas 2018.) Muistaminen ja historiantuottaminen ilmenevät myös visuaalisesti, audiovisuaalisesti, kehollisesti, performatiivisesti sekä suhteessa esineisiin ja paikkoihin. Jos omaehtoisen muistamisen ja historiantuottamisen tapoja halutaan ymmärtää kokonaisvaltaisesti, on selvää, että tutkimuksessa tulee paitsi analysoida verbaalisia muistamisen käytäntöjä, myös tarkastella muita muistamisen medioita. Se edellyttää laajemminkin huomion kiinnittämistä muistamisen materiaalisten ja diskursiivisten aspektien yhteyteen, vuorovaikutukseen sekä materian ja teknologian toimijuuteen - näkökulmiin, joita on analysoitu muun muassa niin kutsutun uusmaterialismin piirissä. Uusmaterialismi - tai uusmaterialismit - viittaa monitieteiseen teoreettiseen ja metodologiseen suuntaukseen, joka on viime aikoina noussut merkittävään asemaan humanistisessa tutkimuksessa ja sosiaalitieteissä (esim. Coole ja Frost 2010). Muistitietotutkimuksen piirissä uusmaterialismin näkökulmien hyödyntäminen on kuitenkin vasta aluillaan (ks. kuitenkin Kuusisto-Arponen ja Savolainen 2016). 
Tässä artikkelissa' tutkimme muistamisen materiaalisuutta, monimediaisuutta sekä medioiden yhteistoimintaa ja tarjoumia (affordance) tarkastelemalla kolmea tapausesimerkkiä, jotka kaikki edustavat omaehtoista ja omakohtaista muistamista. Tämän lisäksi sovellamme väljästi uusmaterialismin teorioita omaehtoisen muistamisen tutkimukseen niiden mahdollisuuksia pohtien. Alun perin havaintopsykologiassa kehitetyn ja sittemmin muun muassa viestinnän tutkimukseen omaksutun tarjouman eli affordanssin käsitteellä viitataan olosuhteisiin ja ominaisuuksiin, jotka mahdollistavat esimerkiksi esineiden, ympäristöjen tai medioiden tietynlaisen käytön tietynlaisessa tilanteessa. (Ks. Keane 2015, 27-30.) Tässä artikkelissa tarjoumalla viitataan muistamisen medioiden ominaisuuksiin suhteessa niiden käyttöön. Artikkelissamme kysymme ensinnäkin, mitä muistamisen materiaalisuus ja monimediaisuus tarkoittaa. Toiseksi kysymme, minkälaisia merkityksiä medioiden yhteistoiminnan ja tarjoumien analyysi tuo esiin omaehtoisesta muistamisesta ja historiantuottamisesta. Tavoitteenamme on pohtia, mitä uusia näkökulmia uusmaterialismin teoriat avaavat muistitietotutkimukselle ja sitä kautta monipuolistaa suomalaisen muistitietotutkimuksen piirissä käytyjä, edelleen voimakkaasti muistamisen kielelliseen ja kerronnalliseen ulottuvuuteen keskittyviä keskusteluja.

Lähestymme artikkelissamme muistitietotutkimusta ennen kaikkea folkloristiikan mutta myös laajemminkin etnografisesti orientoituneiden kulttuurien tutkimuksen alojen näkökulmasta. Käytämme tässä artikkelissa omaehtoisen muistamisen ja historiantuottamisen käsitteitä. Niillä tarkoitamme muistelijoiden omasta aloitteesta ja lähtökohdista, itse valitsemansa muodon ja median kautta tapahtuvaa menneisyyden tulkintaa. Näin määriteltynä omaehtoinen muistaminen lähestyy Henry Jenkinsin esittämää ajatusta osallistuvasta kulttuurista, jonka mukaan kaikki voivat halutessaan osallistua kulttuurin tuottamiseen ja jossa kulttuurin tuottaminen ja osallistuminen kietoutuvat toisiinsa ja ammattilaisuuden ja amatööriyden raja hämärtyy. (Jenkins, Ito ja boyd 2016; ks. myös Turtiainen ja Östman 2009; Koski ja Turtiainen, tässä teemanumerossa). Omaehtoinen historiantuottaminen on aina suhteessa ei-omaehtoiseen eli institutionaaliseen historian tuottamiseen ja tulkintaan, mutta ne eivät ole toistensa vastakohtia tai muuttumattomia, vaan toisiinsa kietoutuneita ja alati vaihtelevassa suhteessa. Institutionaalisen tai hallitsevan ja omaehtoisen suhdetta ei välttämättä aina tuoda muistelussa tai institutionaalisessa historiassa selvästi esiin, mutta suhde on merkityksellinen ja rakentuu historiantuottamisen tapahtumissa aina uudestaan. Nämä eri lähtökohdista kumpuavat historiantulkinnat voivat olla rinnakkaisia ja toisiaan myötäileviä tai ne voivat olla vastakkaisia ja toisiaan haastavia. (Kalela 2000, 37-44, 65-67; 2012, 54-81; Heimo 2010a, 16-19.)

Omaehtoinen-termiä käytetään yleisemminkin viime vuosikymmeninä folkloristiikassa yleistyneen kansanomaista ja jokapäiväistä merkitsevän vernakulaarin käsitteen yhtenä suomennoksena. Vaikka vernakulaarin sijaan käytämme tässä artikkelissa omaehtoisuuden käsitettä, tiedostamme, että molempien merkitykset palaavat kansanomaiseen ja valtaapitävien ja alistettujen ryhmien välisiin suhteisiin (Howard 2008; 2010; Noyes 2012; Goldstein ja Shuman 2012; Bastman, Kallio ja Lehtonen, tässä numerossa). Samaan tapaan kuin vernakulaari, omaehtoinen sisältää ajatuksen virallisen, standardoidun tai hallitsevan olemassaolosta. Omaehtoinen vertautuukin Dorothy Noyesin (2012) näkemykseen vernakulaarista kulttuurin arkipäiväisenä järjestyksenä, joka on kehittynyt ihmisten välisessä vuorovaikutuksessa

1 Tämä artikkeli on tehty seuraavien tutkimushankkeiden puitteissa: Ulla Savolainen: Memory Unchained (SA 1308661) ja Transnational Memory Cultures of Ingrian Finns (Helsingin yliopisto); Karina Lukin: Russia as a field and an archive (SA 308618); Anne Heimo: Digital Heritage in Cultural Conflicts (JPICH.DH.17.009). 
ilman institutionaalisen kontrollin ja sääntöjen vaikutusta. Vernakulaarissa kulttuurin "ylä" ja "ala" ovat kietoutuneet dynaamisesti yhteen, mikä näkyy siinä, että luovat ilmaisut ja käytännöt eivät paikannu vain johonkin tiettyyn yhteisöön tai yhteisölliseen toimintaan, vaan ne ammentavat moninaisista kulttuurin ja historian kerroksista, hybrideistä lähteistä ja ilmentävät monitahoista tekijyyttä (myös Primiano 1995; Koski 2011, 19-21). Uusmaterialistinen näkökulma haastaa omaehtoinen-termin mielekkyyden ja peräänkuuluttaa niin hallitsevan kuin ei-hallitsevankin muistelun tarkastelukulmien laajentamista. Uusmaterialististen näkökulmien yhtenä lähtökohtana on pohtia aineellisen kulttuurin toimijuutta, sen suhdetta ei-aineelliseen ja niiden puitteissa on haastettu ennen kaikkea inhimillisen toimijuuden ensisijaisuutta - ja omaehtoisuutta. Mitä jos tarkastelisimmekin muistamista siitä näkökulmasta, että muistelijoiden toiminta olisi materiaalista, jatkuvassa vuorovaikutuksessa erilaisten materiaalisuuksien kanssa sekä aineellisten ehtojen rajoittamaa, mahdollistamaa ja innostamaa?

Artikkelimme alkaa muistitietotutkimuksen ja uusmaterialismin keskeisten lähtökohtien esittelyllä. Tämän jälkeen siirrymme analyysiosioon, joka koostuu kolmesta tapausesimerkistä2. Vaikka tapausesimerkit kytkeytyvät kirjoittajien aiempiin tutkimuksiin, niitä on analysoitu tässä artikkelissa jaetun näkökulman kautta: kiinnittämällä huomiota muistamisen medioihin sekä niiden yhteistoimintaan ja tarjoumiin. Artikkelissamme olemme lähestyneet muistamista ennen kaikkea prosessina ja toimintana, joka tapahtuu inhimillisten ja ei-inhimillisten toimijoiden verkostossa (esim. Latour 2005).

Artikkelin ensimmäisessä tapausesimerkissä keskitytään netissä tapahtuvan omaehtoisen muistamisen monimediaisuuteen erittelemällä vuoden 1918 sisällissodan tapahtumien muistamisen erityispiirteitä. Esimerkin tarkoituksena on havainnollistaa, mitä muistamisen monimediaisuus tarkoittaa, eli esitellä kielellisen, visuaalisen ja materiaalisen merkityksenannon lähtökohtaista yhteenkietoutumista sekä Facebookin toimijuutta omaehtoisessa muistamisessa. Toisessa tapausesimerkissä analysoidaan valokuvaa ja kerrontaa inkerinsuomalaistaustaisen kirjailijan, Ella Ojalan, kirjallisuudessa. Esimerkin kautta tarkastellaan valokuvan olemusta ja tarjoumia materiaalisena ja esittävänä muistamisen mediana sekä havainnollistetaan valokuvien ja kerronnan vuorovaikutusta. Artikkelin kolmannessa tapausesimerkissä keskitytään nenetsien poroturkisvaatteisiin, paanitsoihin, ja analysoidaan niiden materiaalisuuteen kiinnittyvää merkityksenantoa omaehtoisen historiantuottamisen sekä menneisyyden ja nykypäivän välisen suhteen rakentamisen muotona. Esimerkin avulla valotetaan ja puretaan näkökulmia ja valta-asetelmia, joita alkuperäiskansojen menneisyyksien ja aineellisen kulttuurin tutkimukseen on liittynyt. Tarkoituksena on pohtia, minkälaisia tulkintoja esineistä ja pukineista on ollut ja on mahdollista tehdä; esimerkin analyysi ei niinkään pura aiempia kielellisiin merkityksenantoihin liittyviä historiantuottamisen keskusteluja vaan keskittyy aineellisen kulttuurin tutkimuksen lähtökohtien avaamiseen. Päätäntäluvussa tiivistämme artikkelin keskeiset havainnot sekä pohdimme, mitä näkökulmia uusmaterialismin teoriat avaavat muistitietotutkimukselle.

2 Ensimmäinen tapausesimerkki pohjautuu Anne Heimon, toinen Ulla Savolaisen ja kolmas Karina Lukinin tutkimuksiin. He ovat myös tapausesimerkkejä käsittelevien tekstiosioiden ensisijaiset kirjoittajat ja minä-kertojat. 


\section{Muistitietotutkimus ja uusmaterialismi}

Artikkelimme paikantuu suomalaisen muistitietotutkimuksen kentälle, jonka tausta on kansainvälisessä oral history -tutkimussuuntauksessa. Suomalaisen ja pohjoismais-balttilaisen muistitietotutkimuksen kentän erityinen piirre on se, että oral history -näkökulmien rinnalle on tuotu kulttuurisen muistitutkimuksen (cultural memory studies) näkökulmia (esim. Heimo 2010a; 2016; 2017; Kõresaar ja Jõesalu 2016; Savolainen 2015; 2017; 2018). Molemmat tutkimussuunnat ovat monitieteisiä ja niiden tutkimuskohde on osin sama, mutta ne eroavat toisistaan niin tutkimustraditioidensa kuin painotustensakin suhteen (Hamilton ja Shopes 2008, iix-xii). Oral history -tutkimus keskittyy tallentamaan, analysoimaan ja rakentamaan tulkintoja haastatteluissa tuotetusta, muistitietoa sisältävästä puheesta. Muistitiedon informaatiosisällön lisäksi keskeistä on ollut kiinnittää huomiota siihen, miksi ihmiset kertovat menneisyydestä siten kuin he kertovat. Oral historya tehdään kansainvälisesti paljon myös yliopistojen ulkopuolella esimerkiksi erilaisina yhteisölähtöisinä projekteina sekä akateemisten ja ei-akateemisten toimijoiden yhteistyössä. Emansipatoriset lähtökohdat ja tavoitteet ovat olleet tyypillisiä tutkimussuuntaukselle.

Kulttuurinen muistitutkimus on ollut sen sijaan hyvin avoin tutkimuskohteidensa ja -aineistojensa suhteen, joskin taiteen, institutionaalisesti välittyneen ja vaalitun sekä julkisen muistamisen ilmiöiden tutkimus on ollut hallitsevaa. Muisti-termiä käytetään metaforisesti viittaamaan menneisyyden representointiin sosiohistoriallisissa konteksteissa erilaisten välineiden ja ilmaisumuotojen kautta. (Esim. Hamilton ja Shopes 2008, iix-xii; Erll 2008; 2011a.) Kulttuurisessa muistitutkimuksessa muistaminen on käsitteellistetty aktiiviseksi toiminnaksi, sillä tapahtumia ja kokemuksia ei voi jakaa muiden kanssa ilman, että ne artikuloidaan välitettävään muotoon, esimerkiksi kertomuksiksi, valokuviksi tai muistomerkeiksi (Rigney 2018 , 243). Artikkelimme kannalta olennaisia ovat viime vuosikymmeninä etenkin media- ja viestinnäntutkimuksen teorioihin nojaavat keskustelut muistin välittymisestä (mediation) ja välineistä (media). Muistin on katsottu olevan olemassa nimenomaan välittymisen ja uudelleen välittymisen prosesseissa. Muistin välineet ovat monenlaisia: niin puhe, kirjallisuus, rituaalit, esineet, muistomerkit kuin paikatkin voivat toimia muistin välineinä. (Esim. Erll ja Rigney 2009; Erll 2011b; De Cesari ja Rigney 2014.) Huolimatta samansuuntaisista kiinnostuksen kohteista, dialogi oral history -tutkimuksen ja kulttuurisen muistitutkimuksen välillä on pitkään ollut vähäistä, eikä alojen lähentymistä ole juurikaan reflektoitu (Hodgkin ja Radstone 2003, 4-6; Hamilton ja Shopes 2008; Erll 2011a, 53-57). Juuri muistin välittymisen, välittämisen ja näihin liittyvien kanavien ja aineellisuuksien ympärillä käydyt keskustelut mahdollistavat hedelmällisen vuoropuhelun oral history -tutkimuksen ja kulttuurisen muistitutkimuksen välillä.

Suomessa muistitiedosta kiinnostuttiin sekä folkloristiikassa ja etnologiassa että historiantutkimuksessa 1980-luvulla ja se vakiinnutti asemansa 1990-luvulla. Materiaalisuuden pohtiminen ei ollut folkloristisen eikä etnologisen muistitietotutkimuksen keskiössä. Muistitietotutkimuksen varhaisessa vaiheessa folkloristiikan piirissä käytiin keskusteluja muistitiedon ja folkloren suhteesta sekä muistitiedon suullisen ja kirjallisen muodon kysymyksistä, sillä aineistoina käytettiin haastattelujen lisäksi myös kirjoitettuja muisteluaineistoja. Suomalaisen muistitietotutkimuksen varhaiset keskustelut kytkeytyivät myös kollektiivisen, luovan ja omakohtaisen välisiin rajanvetoihin, jotka ovat pitkään olleet keskeisiä folkloristiikan tutkimuskohteen määrittelemisessä (muistitietotutkimuksen ja folkloristiikan suhteesta ks. Peltonen 2006; Savolainen 2015, 59-61). Suomalaiset folkloristit ja muistitietotutkijat totesivat 
kuitenkin jo varhain, että omakohtaisen tai historiallisen kerronnan sekä folkloren välinen ero on kaikkea muuta kuin selkeä. (Peltonen 1996.) Samaa voidaan sanoa myös rajanvedosta, joka koskee yksilölliseksi taiteeksi ja kollektiivisiksi perinteiksi nimettyjen ilmausten suhdetta. Muistitietotutkimuksen kehittyminen ajoittui vaiheeseen, jossa kansatieteessä tai nyttemmin (eurooppalaisessa) etnologiassa oli alettu irrottautua aineellisen kulttuurin tutkimuksesta ja erityisesti typologisesta tutkimusotteesta, jonka tiedonintressi oli historiallinen ja jonka puitteissa materiaalisuus toimi historiallisten tulkintojen lähtökohtana. Kuten Orvar Löfgren on todennut, erityisesti ruotsalaiset mutta laajemmin muutkin Euroopan etnologit ${ }^{3}$ pyrkivät 1960- ja 70-luvuilta alkaen irtaantumaan aiemmasta aineellisen kulttuurin dokumentoimiseen, kartoittamiseen, kehittymiseen ja leviämiseen liittyvistä kysymyksenasetteluista. Huomio siirtyi symbolijärjestelmien ja semioottisen toiminnan tutkimiseen, ja materiaalisen kulttuurin aineellisuus ja käytännöllisyys jäivät taka-alalle. (Löfgren 1997; 2012.)

Vaikka kansainvälinen oral history -tutkimus on keskittynyt haastattelussa tuotettuun muistelupuheeseen, myös muiden medioiden roolia muistelutyössä on jonkin verran pohdittu (ks. esim. Summerfield 2019). Merkittävin näistä medioista on kenties ollut valokuva, vaikka pohdinta haastattelussa tuotetun muistelun ja valokuvan suhteesta on ollut vähäistä (Freund ja Thomson 2011a, 2-3; ks. kuitenkin esim. Langford 2001). Valokuvaa onkin tavallisimmin käytetty lähinnä virikkeenä tai muistelupuheen sisältöä todentavana evidenssinä (kattava esitys tutkimuksesta Freund ja Thomson 2011a). Verkossa tapahtuvaa muistamista ja historian rakentamista ei ole myöskään tutkittu kovin runsaasti muistitietotutkimuksen piirissä, vaikka tällä hetkellä ne tapahtuvat merkittäviltä osin verkossa mitä moninaisimpien välineiden, niin äänen, kirjoituksen kuin kuvan kautta (ks. kuitenkin Heimo 2014; 2017). Ylipäätään kokonaisvaltaiset hahmotukset muistin medioiden rooleista ja vuorovaikutuksesta omaehtoisessa muistamisessa loistavat poissaolollaan.

Tässä artikkelissa lähestymme omaehtoista muistamista, sen välittymistä ja materiaalisuutta soveltaen väljästi uusmaterialismin teorioita. 1990-luvulla nimetty uusmaterialismi viittaa monitieteiseen filosofiseen ja teoreettiseen suuntaukseen (esim. Coole ja Frost 2010; Dolphijn ja Tuin 2012). Se pyrkii purkamaan modernistisille ja humanistisille traditioille leimallisia dualistisia asetelmia, kuten henki-materia, mieli-ruumis, kulttuuri-luonto tai abstrakti-konkreettinen. Posthumanismin tapaan uusmaterialismi kyseenalaistaa materian passiivisuutta sekä ihmis- ja subjektikeskeisyyttä korostavaa ajattelua. Uusmaterialismi korostaa, että ihminen ei ole erityinen suvereeni subjekti vaan osa materiaalista todellisuutta. (Coole ja Frost 2010, 3-10.) Kun yllä esitettyjen dualismien vastakkainasetteluista luovutaan, materiaalisten, biologisten, symbolisten ja diskursiivisten kategorioiden väliset rajat hälventyvät ja ilmiöt muuttuvat "virtaaviksi", "värähteleviksi", "prosessuaalisiksi" ja "relationaalisiksi" (Barad 2007; Bennett 2010; Dolphijn ja Tuin 2012, 33-34). Tämän artikkelin näkökulmasta keskeistä on se, että uusmaterialistinen ajattelu kyseenalaistaa käsityksen merkitysten ensisijaisesti kielellisestä olemuksesta (myös Lehtonen 2014, 10-11). Lisäksi merkittävää on aineellisen tarkasteleminen osana kokonaista inhimillisten ja ei-inhimillisten toimijoiden verkostoa (Latour 2005; myös esim. Coole ja Frost 2010; Bennett 2010; Barad 2007) sekä huomion suuntaaminen materiaalisen ja diskursiivisen yhteenkietoutuneisuuteen menneisyyksien merkityksellistymisessä etäisten ja etäännyttävien historiallisten tulkintojen sijaan (Ingold 2012; Keane 2008; Bell 2017). 
Artikkelissamme sovellamme tältä pohjalta uusmaterialismin teorioita suuntaamalla huomion omaehtoisen muistamisen prosessuaalisuuteen, sen välineiden relationaalisuuteen sekä materiaalisen ja diskursiivisen vuorovaikutukseen merkitysten muodostumisessa. Haluamme materian heijastamien merkitysten sijasta tarkastella muistamisen tarjoumia eli sitä, miten esimerkiksi esineet, teknologiat ja asiat esiintyvät ja toimivat ihmisten elämässä ja omaehtoisessa muistamisessa välineinä, kohteina, mahdollistajina ja toimijoina. Tällä tavoin esineellinen kulttuuri liittyy nykyisyyteen tavalla, jossa sen menneisyys on läsnä sekä materiaaleihin liittyvien ekologisten, tuotannollisten ja taloudellisten prosessien välityksellä että niiden semioottisten ideologioiden (Keane 2018) myötä, jotka vaikuttavat esineisiin liittyvään merkityksenantoon ohjaavina selitysmalleina. Muistamisessa esineiden voima voi tulla esiin paitsi näiden prosessien avaamisen mahdollistajana että strategisena pisteenä, josta käsin menneisyyttä tuotetaan nykyisyydessä (Hirsch and Spitzer 2006; Savolainen 2018).

\section{Netin muistojulkaisut ja omaehtoisen historian rakentamisen prosessi}

Seuraavassa tapausesimerkissä havainnollistetaan sitä, mitä muistamisen monimediaisuus tarkoittaa tarkastelemalla netissä tapahtuvaa muistelua ja sen erityispiirteitä, erityisesti visuaalista ja kielellistä merkityksenantoa liittyen vuoden 1918 sisällissodan tapahtumiin. Älypuhelinten yleistyminen 2010-luvulla on lisännyt valokuvien käyttöä sosiaalisessa mediassa siinä määrin, että voidaan puhua sosiaalisen median visuaalisesta käänteestä (visual turn). (Ks. esim. Faulkner, Vis ja D'Orazio 2016, 160.) Tämän seurauksena sosiaalisen median jatkuvassa uutisvirrassa on nykyään vaikea herättää huomioita pelkällä tekstillä, vaan tekstin yhteyteen lisätään usein visuaalinen komponentti, kuten kuva tai video. Kuten digitaalisen antropologian tutkija Daniel Miller tutkimusryhmineen on todennut: "We used to just talk, now we talk photos" (Why we post, Discoveries 7).

Yksi muistitietotutkimuksen peruslähtökohdista on tuoda esiin historiantutkimuksen marginaaliin jääneiden kokemuksia heidän omista lähtökohdistaan käsin. Tämä on tapahtunut pääasiassa, etenkin kansainvälisessä kontekstissa, julkaisemalla haastatteluihin perustuvia tutkimuksia, radio- ja tv-dokumentteja sekä näyttelyjä. Sen sijaan verkon ja sosiaalisen median suosion kasvun ja arkipäiväistymisen vaikutukset muistitietotutkimukselle ovat jääneet vähäiselle huomiolle, vaikka ne tarjoavat aiemmin marginaaliin jääneille ryhmille ja yhteisöille mahdollisuuden kertoa omasta menneisyydestään omaehtoisesti. Muistitietotutkimuksen piirissä tietotekniikan ja digitaalisen teknologian yleistyminen on merkinnyt lähinnä uusia keinoja tallentaa, analysoida, arkistoida ja julkaista muistitietoaineistoja. (Ks. esim. Thomson 2007; Boyd ja Larson 2014.) Yksi syy netin sivuuttamiselle on tutkimussuuntauksen vahva sitoutuminen haastattelumenetelmään, vaikka tosiasiassa ihmiset hyödyntävät kaikkia käytössään olevia keinoja ja välineitä niin muistellessaan kuin muissa omaehtoisissa toimissaankin. Folkloristi Dorothy Noyes $(2016,64,66)$ esittääkin, että omaehtoiselle toiminnalle on ominaista eri lähteistä peräisin olevien tietojen yhdistäminen. Nämä lähteet voivat olla perinteisiä, ammattimaisia, vaihtoehtoisia tai kaupallisia.

2000-luvulta lähtien sosiaalinen media ja blogit ovat muodostuneet keskeisiksi paikoiksi muistelulle. Väitöstutkimuksessani tarkastelin vuoden 1918 paikallisia tulkintoja omaehtoisen historiantuottamisen näkökulmasta (Heimo 2010a). Vaikka netti oli jo tällöin kulttuurisesti omaksuttu ja osa suomalaisten arkea (Suominen 2009), en vielä tutkimuksessani huomioinut netin merkitystä historiallisen tiedon lähteenä ja välityskanavana. Havahtumiseni asiaan tapahtui vasta myöhemmin tutkimukseni jo ilmestyttyä (Heimo 2010b; Heimo 2014). 
Netti ei ainoastaan tarjoa uusia lähteitä muistelun tutkijoille, se myös tekee näkyväksi prosessin, jonka tunnistaminen ja dokumentoiminen on vaatinut aiemmin pitkäaikaista kentällä oloa. Nyt on mahdollista seurata reaaliaikaisesti tai jälkikäteen tietokoneen tai muun älylaitteen ruudulla, miten inmiset etsivät, tuottavat ja jakavat menneisyyttä koskevia tietojaan ja muistojaan. Mediatutkijat ja kulttuurisen muistin tutkijat kiinnostuivat digiajan muistamiskäytännöistä jo yli vuosikymmen sitten (ks. esim. van Dijck 2007; Garde-Hansen, Hoskins ja Reading eds. 2009; Gibbs, Meese, Arnold, Bjorn, ja Carter 2015), mutta folkloristiikassa tutkimus on toistaiseksi ollut vähäisempää.

Netissä tapahtuvan muistamisen tarkastelu vaatii "sotkuisia menetelmiä", jolla mediatutkija Susanna Paasonen $(2013,34)$ tarkoittaa eri aloilla käytettävien menetelmien yhdistämistä ja soveltamista. Tutkija ei voi lähestyä nettiä pelkästään tietynlaisena alustana tai viestintäkanavana, jota ihmiset käyttävät keskinäiseen kommunikointiin, vaan hänen on huomioitava, että kyse on "ihmisten, teknologioiden ja ilmaisumuotojen välisistä suhteista ja vuorovaikutuksesta, sosiaalisesta vaihdosta, läsnäolon ja suoruuden tunteesta" (Paasonen 2013, 34). Tästä seuraa, että jokaiselle sosiaalisen median alustalle syntyy omanlaisensa kommunikaatio- ja käyttömuoto. (Gibbs et al. 2015, 257.) Myös eettisten kysymysten ratkaiseminen vaatii netin erityispiirteiden huomioimista. (Turtiainen ja Östman 2013; Kosonen et al. 2018; ks. myös Paasonen 2013, 34.) Keskeisiä verkkoetnografian muotoja ovat osallistuva havainnointi tai pelkkä havainnointi netissä, joista jälkimmäisen eettisyydestä tutkijat ovat erimielisiä. Etenkään piilohavainnointia ei pidetä eettisesti kestävänä ratkaisuna, vaikka se on yleistä ja vaikka monissa tapauksissa havainnoinnin kohteiden, kuten Facebook-ryhmien kaikkien jäsenten informoiminen tutkimuksesta on käytännössä mahdoton tehtävä. Itse olen esittäytynyt ryhmien ylläpitäjille ja pyytänyt siinä vaiheessa luvat julkaisijoilta, kun olen halunnut käyttää heidän julkaisujaan tutkimuksissani. Yhteydenottoihini on suhtauduttu enimmäkseen positiivisesti. Ihmiset ovat olleet kiitollisia tutkijalta saamastaan huomiosta asialleen. Joissain tapauksissa tutkimuksistani on tullut osa heidän tiedonlähteitään, joihin he viittaavat myöhemmissä muistojulkaisuissaan.

Kummatkin esimerkkini on julkaistu suljetussa Facebook-ryhmässä, joten ilman julkaisijoilta saatua lupaa niitä ei voisi käyttää. Vaikka olen saanut kummaltakin muistelijalta luvan käyttää heidän muistojulkaisujaan tutkimuksissani, olen silti joutunut pohtimaan erilaisia kysymyksiä. Ovatko muistojulkaisut julkisia vai eivät? Molemmissa tapauksissa muistelijan tavoitteena on ollut pitää sukulaistensa muistoa yllä, lisätä tietoa sisällissodassa kuolleiden kohtaloista ja löytää lisää tietoa aiheesta. Kumpi tutkimuksessani on tärkeämpää, henkilöiden suojaaminen vai heidän tekijyytensä tunnustaminen? Onko edes mahdollista suojata muistelijoiden henkilöllisyys, jos he ovat julkaisseet muistojulkaisunsa puolijulkisella sivustolla, jolla on tuhansia käyttäjiä? ${ }^{4}$

Tarkastelemani kaksi muistojulkaisua on valittu lukuisten muiden vastaavien Facebook-julkaisujen joukosta, joissa yhdistyvät muistamisen monimediaiset nykykäytänteet, perhehistoria ja omaehtoisen historian tuottaminen. Vaikka muistelua tapahtuu sosiaalisen median eri alustoilla (ks. esim. Gibbs et al. 2015, 255), erityisesti Facebook-ryhmät ovat otollisia sille. Facebook-ryhmiä voidaan perustaa eri teemojen ympärille ja Facebookissa on helppo linkittää muualla julkaistua materiaalia, kuten YouTube-videoita, blogeja tai digitaalisten

$4 \quad$ Koska tutkimukseni kohteena ovat itse muistojulkaisut eivätkä niiden tekijät, ei muistelijoiden nimien mainitseminen ole välttämätöntä. Olen tästä syystä päättänyt olla mainitsematta kertaluontoisen muistelijan henkilöllisyyden, mutta maininnut paljon julkisuudessa olleen muistelijan nimeltä. 
arkistojen avoimia aineistoja. Kummassakin julkaisussa muistamisen kohteena on sisällissodassa kuolleiden sukulaisten muistaminen yksityisessä Facebook-ryhmässä "Suomen sisällissota 1918", jossa on kirjoitushetkellä noin 4400 jäsentä. Ensimmäisessä esimerkissä muistelija edustaa neljättä sukupolvea ja muistojulkaisu on kertaluontoinen. Toisessa esimerkissä muistelijan kohteena on hänen oma isoisänsä ja tätinsä, joiden kohtaloita muistelija on esitellyt lukuisissa yhteyksissä. Ensimmäisessä esimerkissä muistelun kohteena on minulle tuntematon tapaus, kun taas toisessa esimerkissä tapaukset ovat minulle entuudestaan tuttuja ja olen käsitellyt niitä itsekin aiemmissa tutkimuksissani (ks. esim. Heimo 2010a, 112, 141, 220, 227-230).

Ensimmäinen vappuaattona 2018 Facebookin "Suomen sisällissota 1918"-ryhmässä julkaistu muistojulkaisu on tekstistä ja kolmesta kuvasta koostuva sommitelma "mummon enon", Toivo Vainion muistoksi. Julkaisu sai 24 tykkäystä ja yhden surullisen naaman. Yksi henkilö kommentoi tapausta kertomalla Työväenmuseo Werstaan Punaiset muistomerkit -sivustolta, Orimattilan historiasta ja Suomen Sotasurmat 1914-1922, Sotasampo -tietokannasta löytämiään lisätietoja tapauksesta. Lähteiden mukaan Orimattilan Kuivannossa saksalaisjoukot tai suojeluskuntalaiset ampuivat huhtikuussa 1918 Toivo Vainion lisäksi kolme muuta punakaartilaista, Emil Saarisen, Edvard Tähtisen ja Onni Niemisen. Joissain versioissa vain yksi tai kaksi miehistä ammuttiin ja muut olisivat kaatuneet. Eri lähteiden antamat tiedot tapauksesta ovat keskenään ristiriitaiset, mutta muistelijan kuuleman perhekertomuksen mukaan Toivon olisivat ampuneet nimenomaan suojeluskuntalaiset.

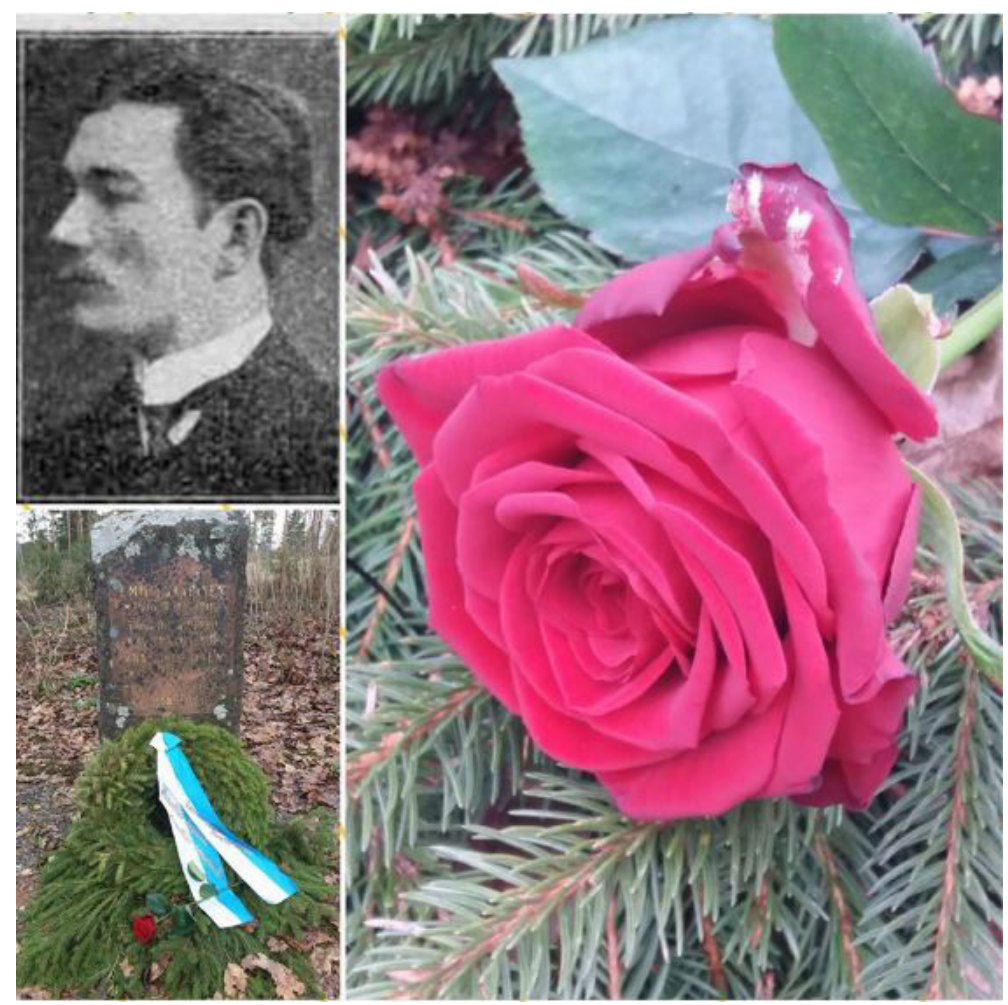

Kuva 1: Muistojulkaisu 30.4.2018. "Rauhallista Vappua! Tämän ryhmän ansiosta tutustuin Itä ja Länsi 1918 muistojulkaisuun ja löysin sieltä oheisen Toivo Vainion, mummoni enon, kuvan. Toivo kuoli 14.4.1918, ja hänet on haudattu Orimattilan Kuivannolle. Tänään kävin Kuivannolla. Ajattelin Toivoa ja muistelin isovanhempiani. Perhehistoriaa ja siihen vaikuttaneita yhteiskunnallisia tapahtumia ymmärtämällä sitä alkaa ymmärtämään omia vanhempiaan ja heidän valintojaan paremmin." (Facebook, kuvakaappaus: Anne Heimo 13.1.2020.) 
Muistojulkaisua ei ole lähetetty hetken mielijohteesta spontaanisti, vaan harkitusti. Muistelija on valinnut nimenomaisen julkaisualustan sekä tehnyt etukäteisvalmisteluja voidakseen julkaista mieleisensä kuvat. Julkaisemalla koosteensa "Suomen sisällissota 1918" -ryhmässä hän osallistui vuoden 2018 sisällissodan muistovuoden viettoon sekä linkitti oman sukuhistoriansa historialliseen yhteiskunnalliseen konfliktiin. Samalla hän noudatti osallistuvaan kulttuuriin (ks. Jenkins, Ito ja boyd 2016) kuuluvaa vastavuoroisuuden periaatetta julkaisemalla muistonsa ryhmässä, jonka avulla hän oli löytänyt kaipaamansa tietoja. Hän oli hakenut sisällissodassa kuolleesta sukulaisestaan lisätietoja eri lähteistä, kuten Itä ja Länsi 1918 -muistojulkaisusta, josta hän oli löytänyt julkaisemansa sukulaisensa kuvan. Muistomerkin pystyttänyt ja siitä huolehtiva Kuivannon työväenyhdistys järjestää vappuisin paikalla muistotilaisuuden, johon muistelijakin oli osallistunut ja josta hän oli ottanut julkaisemansa kaksi muuta kuvaa. Kuvista toisessa näkyy muistomerkki seppeleineen. Toinen kuva on lähikuva paikalle jätetystä punaisesta ruususta, jonka hän on saattanut laskea itse, vaikka ei tästä erikseen mainitse. Tekstissä muistelija korostaa perhehistorian merkitystä menneisyydessä tapahtuneiden asioiden ja ratkaisujen ymmärtämiselle. Hän ei ole yksin näkemyksensä kanssa, vaan perhehistoriasta on viimeisten vuosikymmenten aikana muodostunut yksi tärkeimmistä ja suosituimmista tavoista käsitellä ja ymmärtää menneisyyttä. (Ks. esim. Rosenzweig ja Thelen 1998, 21-22, 89-114; Srigley ja Zembryski eds. 2009.) Tämä koskee myös Suomen sisällissotaa. (Latvala 2005, 188-192; Torsti 2012, 123-126.)

Toinen tarkastelemani esimerkki koostuu kirjailija-runoilija Kaija Olin-Arvolan "Suomen sisällissota 1918"-ryhmässä vuonna 2015 julkaisemasta seitsemästä eri muistojulkaisusta. Olin-Arvolan isoisä Vihtori Lindell ammuttiin Nummen Tavolassa ja hänen setänsä Juho Åhlin vaimo Tekla Åhl Inkoon Västankvarnassa. Lindell ja Åhl kuuluivat kumpikin Sammatin työväenyhdistykseen. Lindell oli punakaartilainen ja Åhl toimi punakaartin keittäjänä. (Heimo 2010a, 112, 141, 220, 227-230.) Olin-Arvola muisteli isoisänsä kohtaloa netissä mitä ilmeisimmin ensimmäisen kerran 2008 julkaistussa blogissaan (Olin-Arvola 2008). Tämän jälkeen hän on kertonut sukulaistensa kohtaloista lukuisia kertoja eri foorumeilla. Olen seurannut Olin-Arvolan muistojulkaisuja vuodesta 2010 lähtien esimerkkeinä omaehtoisen historian tuottamisesta nykypäivänä. (Ks. Heimo 2010b; Heimo 2014.) Olin-Arvola on puolestaan käyttänyt tutkimuksiani lähteinään ja maininnut niistä omissa julkaisuissaan.

Huhti-toukokuun vaihteessa 2015 Olin-Arvola julkaisemissa muistojulkaisuissa aiheina ovat Vihtori Lindellin ja Tekla Åhlin kohtalot ja näihin liittyvät paikat, kuten kummankin hautamuistomerkit, Lindellin pakopaikkana toiminut luola ja valkoisten esikuntana toiminut Ylitalo, jossa

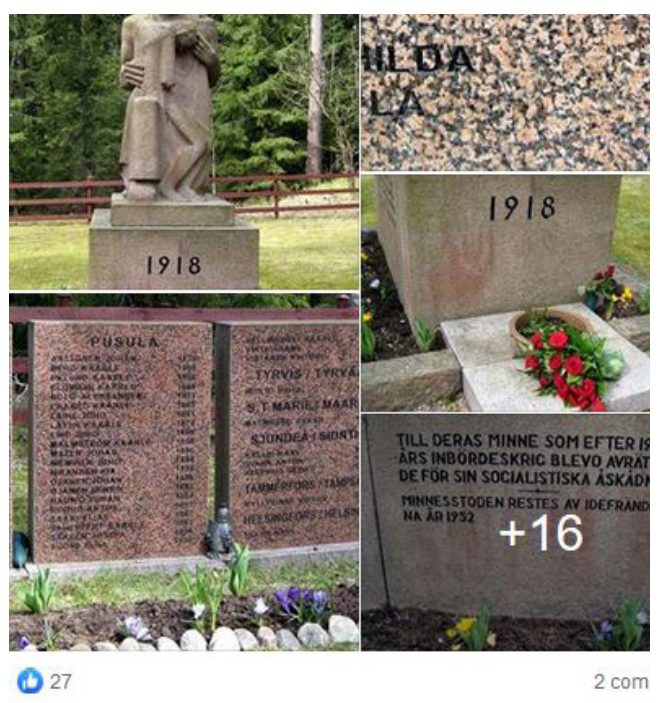

Kuva 2: Muistojulkaisu 1.5.2015: "Kävin tänään myös Västankvarnin haudalla, jonka muistomerkin on suunnitellut Aimo Tukiainen. Muistomerkille ohjaa hyvin vaatimaton kyltti. Opasteet alkavat jo olla kohta uusimisen tarpeessa. Pelto, jolla Tekla Åhl aikoinaan teloitettiin, kasvaa rikkaruohoa. Tekla Åhlin muistoksi liitän tähän kuvan hänen nimikoimastaan tyynyliinasta. Joku on joskus sanonut, että hauta muuttuu muistomerkiksi, kun ihmiset lakkaavat siellä käymästä. Ainakaan Västankvarnissa ei ole lakattu. Viimeksi kun kävin siellä, oli veistoksen kantapäästä lyöty pala pois. Nyt se oli korjattu." (Facebook, kuvakaappaus: Anne Heimo 13.1.2020.) 
Lindell oli vangittuna ennen teloitustaan. Mukana on myös valokuva Tekla Åhlin nimikoimasta tyynyliinasta. Kukin kooste koostuu tekstistä ja vähintään kolmesta kuvasta. Västankvarnan muistomerkkiä käsittelevässä koosteessa on peräti 21 kuvaa (ks. Kuva 2). Teksteissä Olin-Arvola kertoo perhemuistojaan sekä eri lähteistä peräisin olevia tietojaan tapahtumista. Osa julkaistuista kuvista on vanhoja perhekuvia, osa Olin-Arvolan itse ottamia käynneiltään tapahtumapaikoilla ja hautamuistomerkeillä. Julkaisut ovat saaneet kukin 7-28 tykkäystä ja osa on kirvoittanut kymmeniä kommentteja, minkä lisäksi yksittäisiä kuvia on kommentoitu. Kommenteissa inmiset jakavat tietoja ja lähteitä, kertovat vastaavista tapahtumista omissa suvuissaan ja tekemistään selvityksistä sekä vaihtavat mielipiteitä tapahtumien luonteesta ja siitä, millä termeillä tapahtumista voi puhua.

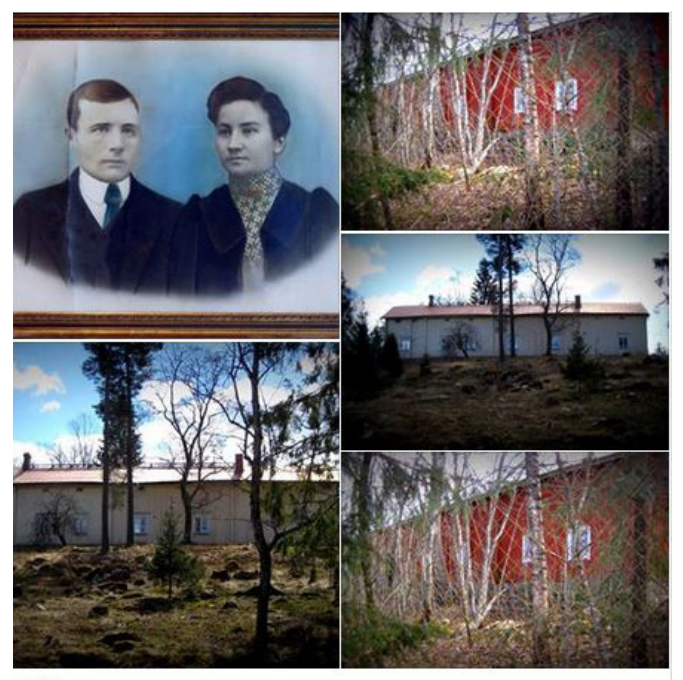

(1) 11
23 comments

Kuva 3: Kaija Olin-Arvolan muistojulkaisu 29.4.2015: "Kuvassa Sammatin Myllykylässä sijaitseva Ylitalo, missä suojeluskuntalaiset ja saksalaiset pitivät päämajaa keväällä 1918. Tilan navetttaan oli vangittu punaisia työväenyhdityksen jäseniä. Sieltä heidät tuotiin taloon kuulusteltaviksi ja kidutettaviksi. Yksi henkilö onnistui pakenemaan sontaluukusta. Yksi haudattiin elävältä talon taakse nummeen. Yksi miehistä oli minun vaarini Vihtori Lindell, joka on kuvassa vaimonsa Ida Matilda Lindellin os. Nyman kanssa. Vaarini rikos oli kuuluminen työväenyhdistykseen. Kun Sammatissa alkoivat vangitsemiset, vaarini piiloutui kahden muun miehen kanssa Ruokoparman luolaan. Heidät antoi ilmi vähämielinen poika, joka oli nähnyt paikalta nousevan savua. Miehet olivat aseettomia. Kiinniotettaessa 1.5. vaariani haavoitettiin päähän ja reisiin. Häntä ei kuitenkaan viety suoraan Ylitaloon, vaan ensin verissäpäin kotinsa pihalle vaimonsa ja kolmen pienen lapsen eteen ja yksi kiinniottajista sanoi: "Kato ny litu Vihtoriis. Ny sää näät sen viimesen kerran". Vasta kuudentena päivänä hän yhdessä 11 muun miehen kanssa joutui kävelemään Nummen Tavolaan n. 12 kilometrin matkan. Siellä hänet ammuttiin ja sotkettiin suohon. Lisää Sammatin tapahtumista linkissä: Anne Heimo: Kapina Sammatissa. Vuoden 1918 paikalliset tulkinnat osana historian yhteiskunnallisen rakentamisen prosessia. http://www.elore.fi/arkisto/2 10/heimo 2 10.pdf " (Facebook, kuvakaappaus: Anne Heimo 13.1.2020.)

Paikkoihin, materiaalisiin objekteihin ja silminnäkijätodistukseen viittaaminen kerronnassa on yleisesti käytetty retorinen keino vahvistaa jonkin asian tapahtuneen (Heimo 2010a, 62-67; Kuusisto-Arponen ja Savolainen 2016). Netissä kuvien käyttö toimii vastaavanlaisena retorisena keinona, jonka avulla voidaan todistaa kerrottujen asioiden tapahtuneen. Tämä keino nojaa valokuvan luonteeseen erityisenä esittävänä mediana, joka ei ainoastaan esitä kohdettaan. Kuvan olemassaolo edellyttää, että kuvattava kohde on todella joskus ollut kameran edessä. (Barthes 1983, 76-81; Hirsch 1997, 5-6.) Kummassakin esimerkissä muistojen paikkansapitävyyttä vahvistetaan julkaisemalla aiemmin muualla julkaistuja valokuvia sekä muistelijoiden itsensä ottamia valokuvia tapahtumapaikoilta ja hautamuistomerkeillä käynneistään. On vaikea kiistää, että jokin muistelluista asioista ei olisi tapahtunut, kun sen puolesta todistavat sekä kertomukset että kuva-aineisto.

Matkatessaan mediasta toiseen ja medioiden vuorovaikutuksessa muistot muuntuvat, altistuvat uusille tulkinnoille ja saavat uusia merkityksiä (Erll 2011b, 9-13; De Cesari ja Rigney 
2014, 4-5). Facebookin kaltaiset teknologiat eivät ole ainoastaan passiivisia kanavia, joita ihmiset käyttävät omiin tarkoituksiinsa, vaan ne muovaavat ja määrittävät muistamista aktiivisesti. Kyse on tarjoumista sekä toimijoiden, ihmisten ja teknologioiden välisestä vuorovaikutuksesta. Facebook mahdollistaa kuvan ja tekstin sekä ihmisten välisen vuorovaikutuksen uudella tavalla myös omaehtoisessa muistamisessa. Facebook, kuten netti yleisesti on myös väljentänyt ymmärrystämme yksityisyyden ja julkisen muistamisen rajoista. Aiemmin lähinnä lähipiirissä jaetut muistot jaetaan yhä useammin julkisilla foorumeilla, jolloin mahdollisuutemme hallita niiden kiertoa yhä uusille foorumeille heikkenee. Muistelijoiden "Suomen sisällissota 1918" -Facebook-ryhmässä julkaisemat muistot sukulaisistaan eivät ole enää pelkästään yksityisiä perhemuistoja, vaan Facebook yhdessä muistelijoiden kanssa on muuntanut ne osaksi sisällissodan julkista muistia. Samalla esimerkit tarjoavat mahdollisuuden tarkastella omaehtoisen historian rakentamisen prosessia tänä päivänä.

\section{Valokuvan ja kerronnan vuorovaikutus}

Seuraavassa tapausesimerkissä tarkastellaan valokuvan tarjoumia sekä valokuvien ja kerronnan vuorovaikutusta omaehtoisessa muistamisessa kirjallisuuden kontekstissa. Tämän kautta pohditaan myös muistamisen medioiden sekä materiaalisten ja diskursiivisten ulottuvuuksien vuorovaikutuksen analyysin mahdollisuuksia. Ella Ojala (1929-2019) on inkerinsuomalaistaustainen kirjailija, joka on kirjoittanut kolme muistelmaromaania ${ }^{5}$ Pitkä kotimatka (1988), Suomi näkyy (1990) ja Ensimmäinen kevät (1994). Niissä kerrotaan kirjojen päähenkilö Elisan ja hänen perheensä elämästä Inkerinmaalla Neuvostoliitossa toisen maailmansodan aikana, perheen evakuoinnista ja asettumisesta Suomeen jatkosodan aikana sekä Elisan varttumisesta lapsesta aikuiseksi inkeriläispakolaisena Suomessa. Vaikka teosten päähenkilöä ei ole nimetty täsmällisesti kirjailijan mukaan eikä kirjojen kerronta ole minä-muotoista, niiden takakansi- ja sisälehtiteksteissä kerrotaan suoraan, että kirjailija itse on "kirjassa kuvatun perheen tytär Elisa", ja että ne perustuvat hänen kokemuksiinsa.

Vuonna 1991 Ojala julkaisi myös valokuvateoksen Pelastunut albumi, jossa hän kertoo omakohtaisesti elämästään sekä perheensä ja sukunsa jäsenten kohtaloista Neuvostoliitossa pelastuneiden perhe-, suku- ja kouluvalokuvien avulla. Pelastuneella valokuva-albumilla on tärkeä rooli myös Ojalan muistelmaromaaneissa. Valokuvateoksensa ensimmäisessä luvussa "Albumin vaiheet" Ojala kertoo lyhyesti valokuva-albumin tarinan. 1930-luvun alkupuolella Ojalan perhe oli karkotettu heidän kotikylästään Lempaalasta Pohjois-Inkeristä sisä-Venäjälle monien muiden inkerinsuomalaisten tavoin. Toisin kuin monien muiden karkotettujen, heidän oli onnistunut paeta takaisin Länsi-Inkeriin ja asettua sinne kolhoosiin. Toisen maailmansodan aikana Saksan hyökätessä kohti Leningradia Ojalan perhe ja kylän väki jäivät Saksan joukkojen ja puna-armeijan väliin. Perhe yritti ensin paeta puna-armeijan rintamalinjojen taakse Leningradiin, mutta äidin sairastumisesta johtuen perhe ei päässyt pakomatkalle, vaan he majoittuivat muutaman kilometrin päähän kodistaan. Matkavalmisteluina he kuitenkin ehtivät kätkeä omaisuuttaan maakuoppaan ja naapurin kellariin. Kätketyn omaisuuden joukossa oli myös perhevalokuva-albumi.

Sotatilanteen rauhoittuessa hetkellisesti 12-vuotias Ojala oli lähtenyt etsimään kätkettyä omaisuuttaan. Kellariin, jossa perheen tavarat olivat, oli tunkeuduttu ja tavarat oli viskottu ympäriinsä. Myös valokuvat oli revitty albumista irti. Ojala kuitenkin löysi valokuvat ja sai

$5 \quad$ Teokset on nimetty muistelmaromaaneiksi niiden kansiteksteissä. 
mukaansa myös muita tavaroitaan. Paluumatkalla hän joutui keskelle pommitusta ja heittäytyi ojaan pelastamiensa tavaroiden päälle suojaten niitä omalla kehollaan. Tämän jälkeen pelastettu valokuva-albumi muutti perheen mukana heidän asuessaan useissa taloissa Saksan valloittamassa Inkerissä. Kun inkerinsuomalaisia alettiin evakuoida Viron kautta Suomeen vuonna 1943, myös albumi kulkeutui Suomeen vaikkakin eri laivassa kuin Ojalan perhe. Lopulta he saivat valokuva-albumin kuitenkin takaisin, ainoana Inkeristä tuotuna tavaranaan.

Valokuvateoksessaan Ojala $(1991,8)$ kertoo, että albumi oli tärkein "[e]sineistä, jotka merkitsivät minulle kotia." Valokuvat olivat ainoita muistoja Neuvostoliiton vainoissa vangituista, karkotetuista, kadonneista ja kuolleista sukulaisista. Kuten jo aiemmin todettiin, Barthes (1983, 76-81) on korostanut valokuvan erityistä kykyä sekä edustaa kohdettaan että viitata siihen. Kulttuurisen muistin tutkija Marianne Hirsch $(1997,5-6)$ on tuonut esiin, että Barthesille valokuva ei ole ainoastaan visuaalinen edustuma menneestä todellisuudesta. Tämän lisäksi valokuva on siinä kuvatun kohteen, menneisyyden todellisuuden, fyysinen ja materiaalinen jatkumo. Siten se mahdollistaa myös katsojalle erityisen yhteyden tähän kohteeseen. Tämänkaltaiseen materiaaliseen yhteyteen epäilemättä perustuu myös Ojalan perhevalokuvien merkitys perhekalleuksina. Ne eivät ainoastaan kuvaa, vaan materialisoivat vainoissa kadonneita perheenjäseniä.

Ojalan taiteessa ja muistamisen mediana perhevalokuva-albumi on kuitenkin olemassa ennen kaikkea toisten medioiden, muistelmaromaanin ja valokuvateoksen osana, rinnalla ja suhteessa niihin. Valokuvateoksensa ensimmäisessä luvussa Ojala rakentaa albumin vaiheet jännittäväksi, ihmeelliseksikin, mutta omakohtaiseksi kertomukseksi. Albumi oli monta kertaa vaarassa tuhoutua, mutta kuin inmeen kaupalla sukuvalokuvat pelastuivat ja "kulkeutuivat" Ojalan valokuvateoksen materiaaliksi. Teoksensa kirjallisissa osioissa Ojala myös ikään kuin täydentää valokuvien visuaalista ulottuvuutta kuvaamalla sanallisesti vanhojen mustavalkoisten kuvien esittämien asujen värejä, kankaiden materiaaleja sekä kuvien ihmisten myöhempää ulkonäköä. Hän on jopa sisällyttänyt valokuvateokseensa sanallisen kuvauksen valokuvasta, joka oli liian haalea uudelleen painettavaksi kirjassa. Ojala on kirjoittanut teokseensa myös muistojaan kuvissa esiintyvistä sukulaisistaan. Hän kertoo, että alun perinkin osa kuvista on "vaeltanut" albumiin "Aasian kuumilta puuvillapelloilta, jäätävästä Siperiasta tai yhtä kylmiltä alueilta Kuolan niemimaalla" (Ojala 1991, 14). Ojala kertoo valokuvien sukulaisten kovista kohtaloista, heidän kärsimyksistään ja menetyksistään. Useampi valokuvista liittyy hautajaisiin tai häihin. Monet Ojalan valokuvista ovat myös viimeisiä ja ainoita muistoja kadonneista ja kuolleista. Kuviin kytkeytyy tyypillisesti myös kirjallisia kuvauksia kuvien henkilöiden onnellisemmasta elämästä, heidän lapsistaan, rakkauksistaan ja erityisistä luonteenpiirteistään. Yhdistettynä kertomuksiin valokuvat synnyttävät kaksoiskuvia - kuvia onnesta ja kärsimyksestä, elämästä ja kuolemasta, poissa- ja läsnäolosta. Nämä kaksoiskuvat syntyvät medioiden vuorovaikutuksesta.

(Perhe)valokuvan tutkijat ovat havainneet hyvin samansuuntaisesti, että kuolema ja elämä kietoutuvat erottamattomasti yhteen valokuvassa. Hirsch $(1997,5,19-20)$ huomauttaa, että koska valokuva on suorassa materiaalisessa yhteydessä valokuvattuun henkilöön ja menneisyyteen, se on samanaikaisesti sekä kuoleman enne että merkki elämästä. Valokuvan kohde on kuin haamu, joka häilyy valokuvan ympärillä muistuttaen kuolemasta ja menetyksestä. Se on yhtäältä läsnä, esitettynä valokuvassa, ja toisaalta poissa - läsnä olevana kuvaushetkellä mutta poissa olevana kuvan katselun hetkellä. (Ks. myös Sontag 1977.) Hirsch (1997, 
20) toteaakin, että valokuvan yhteys kuolemaan ja menetykseen ei niinkään ilmennä muistamista luovana nykyhetkeen kiinnittyvänä ja tulevaisuuteen suuntaavana prosessina kuin tuo esiin menneisyyden korostaen samalla sen peruuttamatonta menetystä. Tämä seikka tulee esiin myös Ojalan Pitkä kotimatka -muistelmaromaaniin (1988) sisältyvästä kuvauksesta, jossa päähenkilö Elisa käy noutamassa kuvat naapurin kellarista, minne ne oli lähdön hetkellä piilotettu ja löytää sekamelskasta oman lapsuuskuvansa, joka todistaa sekä Elisan lapsuudesta että sen katoamisesta (kyseessä on sama kuva, joka on myös Ojalan valokuvateoksen kannessa):

Hänen käteensä osui seuraavaksi suurisilmäisestä lettipäisestä tytöntylleröstä otettu kuva:Tytöllä oli yllään kaunis puku, jonka alta vilkkui viekottelevasti alushameen pitsiä, ja hänen kädessään oli tekokukkakimppu. [...] Siitä tuittupäisestä Elisasta olivat jäljellä vain suuret silmät ja vahva tukka. Nykyisin hän oli laihaksi venähtänyt koulutyttö, joka oli lennähtänyt tänne kellariin kuin joltakin toiselta tähdeltä kokoamaan entisyyden sirpaleita talteen - lentääkseen täältä taas kohti jotakin tuntematonta. (Ojala 1988, 155-166.)

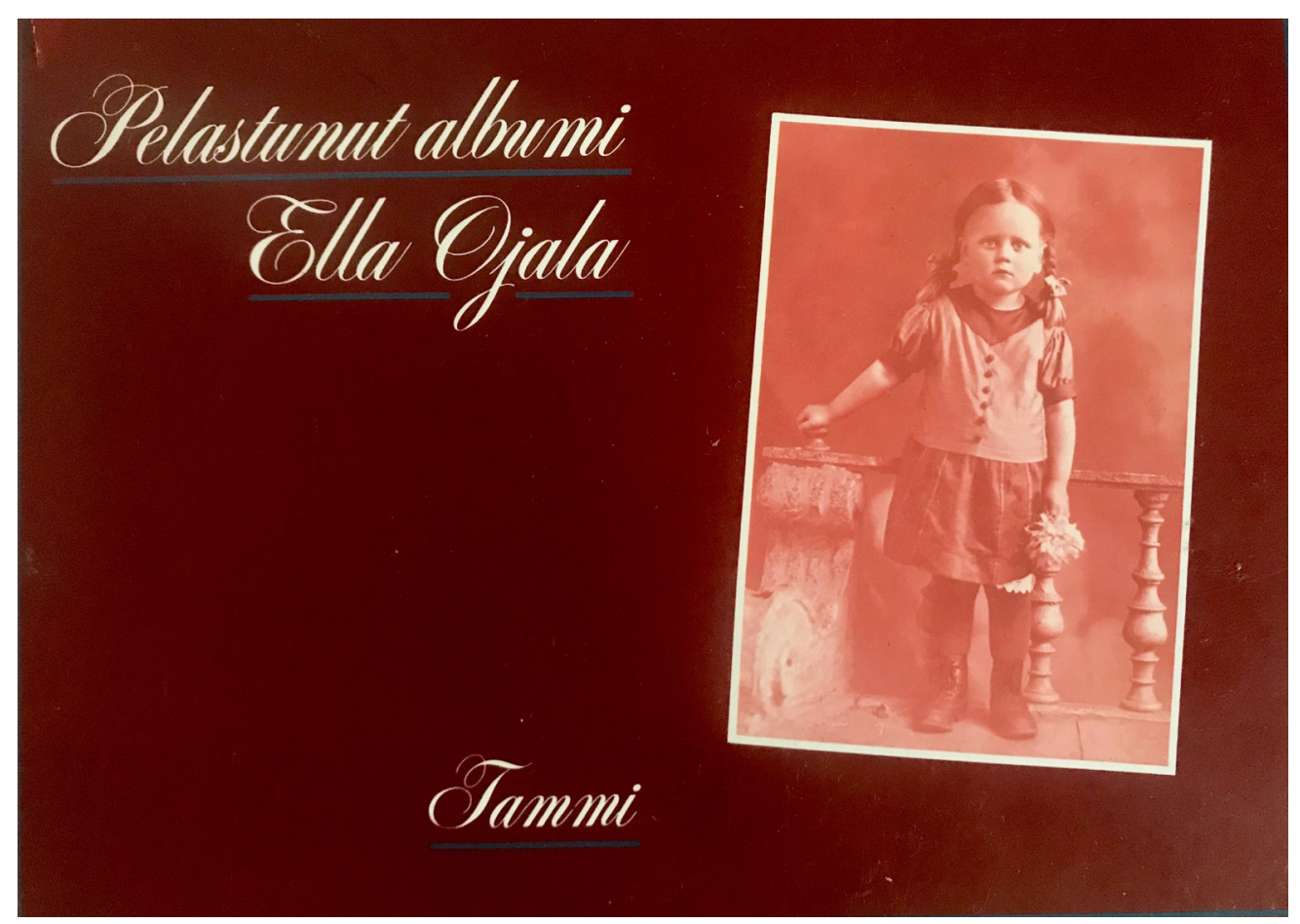

Kuva 4: Pelastunut albumi -valokuvateoksen kansikuva.

Valokuvan erityinen tarjouma muistamisen kannalta perustuu siihen, että se viittaa indeksisesti kohteeseensa eli menneisyyteen valokuvan katsomisen nykyhetkessä tai vähintäänkin luo vaikutelman tällaisesta ajallisesta, materiaalisesta ja kausaalisesta yhteydestä. Ella Ojalan pelastuneen valokuva-albumin ja sen myöhemmän kirjallisen elämän analyysin pohjalta voidaan kuitenkin todeta, että sen lisäksi, että valokuva on esittävä media, jonka suhde kuvaamaansa menneeseen todellisuuteen on erityinen, valokuvat ovat myös esineitä, joiden toimijuus, tarjoumat ja käyttötavat muistelun kontekstissa eivät rajoitu yksinomaan niiden olemukseen valokuvina. Sen lisäksi valokuvat ovat olemassa ja vaikuttavat maailmassa osana medioiden - kuten kuvan ja kertomuksen - sekä toimijoiden - kuten Ella Ojalan ja albumin - vuorovaikutteista ja dynaamista verkostoa tai systeemiä (Latour 2005; Ingold 2012), jossa muistaminen tapahtuu. 
Yksi esimerkki tästä medioiden ja toimijoiden dynaamisesta yhteistoiminnasta on se, että asettuessaan vuorovaikutukseen muistelmaromaanien ja valokuvateoksen kanssa Ojalan valokuvien toimintakenttänä ei ole enää yksinomaan yksityinen henkilökohtaisen elämän tai perheen ja suvun piiri (jos se sitä on koskaan ollutkaan). Sen lisäksi, että ne edustavat kuvaamiaan ihmisiä ja menneisyyksiä nykyisyyden perhemuistelun yhteydessä, valokuvat ovat muuttuneet julkisiksi, sekä omakohtaisten että kollektiivisten kokemusten muistamisen sekä myös niistä todistamisen ilmentymiksi ja välineiksi. Ensinnäkin, muistelmaromaanin kanssa vuorovaikutuksessa albumi on muuttunut ja laajentunut menneisyyden ja nykyisyyden suhdetta, naiseksi kasvua ja identiteetin kehitystä ilmentäväksi symboliksi. Toiseksi, dokumentaarisen valokuvateoksen kanssa vuorovaikutuksessa albumi on laajentunut myös inkerinsuomalaisten kohtaloa ja maailmanhistorian kulkua ilmentäväksi todisteeksi. Tämä muutos käy ilmi myös valokuvateoksen ensimmäisen luvun viimeisessä kappaleessa, jossa Ojala puhuttelee lukijaa suoraan ja kertoo motiivistaan julkaista teos sukuvalokuvista:

Nämä kuvat ovat kulkeutuneet pitkän matkan päätyäkseen tähän tarkasteltavaksenne. Toivon, että ne vaeltavat edelleen ympäri maailmaa todisteena inkeriläiskansan kohtalosta suurempien tapahtumien jaloissa. Tämä albumi pelastui kertomaan tarinansa. Monien muiden joukossa ne koki silloin pieni Ella Makara - nyt kahden lapsen ja lapsenlapsen Ella-mummi. (Ojala 1991, 14.)

Huomattavaa on myös se, että suhteessa muistelmaromaaneihin, valokuvateokseen sekä kirjailijaan itseensä valokuva-albumi todistaa historiasta myös nimenomaan tytön ja naisen näkökulmasta. Ojalan muistamisessa tytöt ja naiset, ennen kaikkea hän itse, ovat keskiössä. Ajan myötä, Ojalan käsittelyssä sekä ennen kaikkea osana monimediaista verkostoa, pelastuneet valokuvat eivät ole yksinomaan kuvia kohteistaan, jotka muistuttavat heistä tai ilmentävät kuoleman vääjäämättömyyttä, vaan ne kytkeytyvät omaehtoisiin omakohtaisen ja kollektiivisen muistamisen nykyhetkisiin ja olennaisesti tulevaisuusorientoituneisiin prosesseihin. Ojalan taiteessa eriasteisesti omaelämäkerralliset ja sepitteelliset kirjalliset teokset, valokuva-albumi ja kirjailija itse muodostavat sanallisten, visuaalisten ja materiaalisten muistamisen medioiden sekä inhimillisten ja ei-inhimillisten toimijoiden verkoston. Kun materian toimijuus otetaan vakavasti ja materiaalisen ja diskursiivisen vastakkainasettelusta luovutaan ja käännetään huomio niiden vuorovaikutukseen, avautuu myös uudenlaisia mahdollisuuksia ymmärtää todellisuutta. Sen sijaan, että näkisimme valokuvien ja kielellisen kerronnan alisteisessa suhteessa toiseen - siten, että toinen määrittäisi muistelun merkitysten ja seurausten muodostumista toisen ollessa passiivinen kohde tai mekaaninen reaktio - havaitsemme niiden olemuksen toisiinsa kietoutuneiksi ja niihin liittyvät merkitykset lähtökohtaisesti tämän relationaalisen suhteen seurauksiksi.

\section{Poronnahkapukineet, ajoittaminen ja materiaalisuuteen kiinnittyvä merkityksenanto}

Omaehtoisen historian tuottamisen tai sitä koskevien mielikuvien ja ulkopuolisten tekemien historian tulkintojen erot ja suhde asettuvat alkuperäiskansojen tai vähemmistöjen parissa hieman toisin kuin länsimaiden omaehtoiseen historiantuottamiseen keskittyneissä muistitietotutkimuksen tai kulttuurisen muistitutkimuksen suuntauksissa. Vähemmistöt tai alkuperäiskansat ovat tyypillisesti historiankirjoituksen marginaalissa, jolloin heidän historiansa on kirjoitettu osaksi laajempia, esimerkiksi kansallisen historiankirjoituksen kertomuksia. 1800-luvulla kehitettyjen teorioiden mukaan alkuperäiskansat edustivat ihmiskunnan historiaa ja heidän menneisyytensä ja meidän menneisyytemme oli luettavissa heidän 
perinteisestä kulttuuristaan. Ylläkuvatuista muistitietotutkimuksen asetelmista tämä lähtökohta eroaa siten, että kyseessä ei ole pelkästään joidenkin inmisten muistista tai muistoista vaikeneminen, vaan alisteisessa asemassa olevien yhteisöjen kulttuurin tulkitseminen kehyksissä, jotka uusintavat alisteisen aseman lisäksi ei-paikallisia ja yleisiä historian kertomuksia.

Törmäsin itse näihin tulkintoihin ja tulkintojen arvon kiistäviin nenetseihin omien 2000luvun alun kenttätöideni aikana. Nenetsit ovat Venäjän ja Länsi-Siperian arktisilla alueilla elävä alkuperäiskansa. Heidän elämäntapansa on perustunut suurporonomistukseen ja paimentolaisuuteen ja niin akateemisissa kuin populaareissakin kuvauksissa on kiinnitetty huomiota nenetsien poroturkisvaatteisiin. Olin vuonna 2000 ensimmäistä kertaa tekemässä kenttätöitä nenetsien parissa. Matkani oli päätynyt Kolgujevin saaren Bugrinon kylään, ja olin vähä vähältä tutustunut arkeen ja ihmisiin - erityisesti perheeseen, jonka luona asuin. Poronnahkaisia vaatteita tapaa kyläkuvassa silloin tällöin: jokainen omistaa poronnahkaiset kengät, minkä lisäksi tunturissa enemmän aikaa viettävillä inmisillä on käytössään turkisvaatteita. Turkikset ovat käytännöllisiä vaatteita, jotka liittyvät matkantekoon ja ulkotöihin. Toisaalta runsaasti tai huomattavan kauniisti kirjaillut vaatteet ovat juhlapukimia. Kenttätöideni aikana olen havainnut, että etenkin naiset säilyttävät äitiensä ja isoäitiensä turkisvaatteita ja esittelevät niitä kernaasti vieraille. Eräänä iltana Kolgujevin perheeni isoäiti kutsui minut luokseen ja kaivoi varastoistaan paanitsoja, naisten kokopitkiä edestä avoimia turkisvaatteita. Paanitsat olivat kauniisti kirjailtuja ja niiden saumoihin oli ommeltu värikkäitä kangassuikaleita ja jokaiseen turkikseen kuului siihen sopiva poronnahkainen hattu. Tavallisesti sanansa tarkasti valitseva isoäiti puhui puhumasta päästyään; hän oli innoissaan, mutta sanoissa kuului myös närkästys. Hän kertoi isoäidistään ja sukunsa menneisyydestä, naisten tilasta ja työstä kodassa, ompelutaidon tärkeydestä tunturissa asuvien paimentolaisnenetsien elämässä. Erityisesti isoäiti muisteli isoäitiään ja omia aikojaan kodassa äitinä ja emäntänä. Samaan aikaan sormet kävivät mosaiikkikirjontoja pitkin ja silittivät poronkarvaa. Pyysin isoäitiä pukemaan paanitsan päälleen, jotta voisin kuvata hänet siinä. Nainen kieltäytyi, mutta hetken päästä poronnahkaturkki lakkeineen olivat päälläni ja seisoin ulkona hiljaisessa lumisateessa, kun naisen tytär osoitteli minua kamerallani. Samalla kun naiset kieltäytyivät joutumasta etnografisen kuvauksen kohteiksi, he olivat myös opettaneet minulle jotain menneisyyden ja aineellisen yhteenkietoutumisesta.

Päälle pukemani paanitsa oli taryaw' pani 'oravapaanitsa', jossa leikkaukset kulkevat poikkisuoraan muodostaen kolme eri nahoista koostuvaa kerrosta. Ylin on perinteisesti ommeltu oravan (majavan tai ketun) nahoista, keskimmäinen porosta ja alin koirasta tai ketusta. Neuvostoliitossa julkaistiin runsaasti alkuperäiskansojen kulttuurin, sen esineistön ja suullisen perinteen typologisoivaa kartoitusta ja historiallis-vertailevaa analyysiä 1960- ja 70-luvuilla (esim. Anderson ja Arzyutov 2016). Näiden tulkintojen mukaan erityisesti nenetsien läntisillä asuma-alueilla, Kaninin niemimaalla ja Kolgujevin saarella käytettävät naisten turkisvaatteet, oravapaanitsat, edustavat vanhinta kerrostumaa nenetsien vaatetuksessa. Kolmikerroksisuuden on arveltu heijastavan šamanistista maailmankuvaa, mutta muinaisuuteen on liitetty erityisesti se, että malli "kietoutuu" kehon ympärille ja on näin jäänne niiltä ajoilta, jolloin vaatteena käytettiin kokonaisia turkiksia. Koska tästä mallista on tietoja muualla kuin lännessä asuvien nenetsien parissa 1700-luvulta, on mallin arveltu olleen aiemmin suositumpi laajemmaltikin. Pystysuuntaiset leikkaukset ja niihin liittyvän ornamentiikan nenetsit olisivat oppineet myöhemmin Siperiassa eläviltä naapureiltaan, hanteilta ja manseilta; mallina sen on siis tulkittu olevan myöhempää alkuperää nenetsien parissa. (Prytkova 1970, 30-48; Homitš 1966, 124-30; Amelina 2014.) Näiden tulkintojen valossa muutoin hyvin 
paljon vaikutteita venäläisestä kulttuurista saaneiden läntisten nenetsien vaatetus olisi säilyttänyt jopa arkaaiseksi nimetyn omaleimaisuuden. Samalla materiaalisen kulttuurin piirteiden on nähty vahvistavan hypoteesia, jonka mukaan Bugrinossa asuvien nenetsien esivanhemmat olisivat muuttaneet Kolgujevin saarelle juuri nenetsien läntisiltä asuma-alueilta, Kaninin niemimaalta ja Timanin tundroilta.

Antropologisissa keskusteluissa on kritisoitu tämänkaltaisia analyysejä ja niiden taustalla olevia ideologioita. Kritiikin mukaan tulkinnat ovat etäännyttäviä, ja niiden tarve kertoa menneisyydestä nousee modernille tyypillisestä kronologisesta otteesta, jonka puitteissa Johannes Fabianin (1983) ja James Cliffordin (1988) havaintoja mukaillen tämänpäiväinen materiaalinen kulttuuri asettuu merkitykselliseksi vain menneisyyden heijastumana, perinteenä tai primitiivisenä (esim. Löfgren 2012,171). Viime aikoina on myös huomautettu, että typologinen näkökulma on asettanut esineet, niiden tekijät ja käyttäjät niin yksilöinä kuin yhteisöinäkin erilleen (Bell 2017; Bruchac 2018, 71-73). Käyttäjien, tekijöiden ja yhteisöjen häivyttäminen (erasure) heijastuu myös siinä, miten aiemmissa tutkimuksissa on epäonnistuttu näkemään ne omaehtoisen historian rakentamisen ja käsitteellistämisen tavat, joita esineisiin sisältyy.

Paanitsoja esiin kaivanut isoäiti oli kiistämässä ulkopuolisten tutkijoiden kirjoittamien historioiden ylivoimaista arvoa ja halusi tehdä sen turkisvaatteiden avulla, koska juuri niihin on tutkimuskirjallisuudessa liitetty historiallisia tulkintoja. Isoäidinkin kirjahyllyssä oli neuvostoaikaisia nenetsien etnografiasta kertovia klassikkoteoksia, joita silmäilemällä hän oli vakuuttunut siitä, että etnografisen katseen toiseuttava luonne ei tehnyt oikeutta hänen elämänsä nykyajalle. Se, mikä etnografisissa teksteissä kerrottiin menneessä aikamuodossa, oli hänen elämäänsä, hänen kolmikerroksinen paanitsansa. Hän oli loukkaantunut siitä, että hänen ja hänen esiäitiensä ompelemat vaatteet redusoitiin osaksi Siperian alkuperäiskansojen asutushistoriaa. Närkästys kirvoitti puhumaan, mutta todennäköisesti isoäiti halusi kehottaa minua tekemään toisin.

Siperian alkuperäiskansojen asutushistoriat mainittuaan isoäiti kertoi juuri käsillä olevien paanitsojen tekijöistä, toisin sanoen itsestään ja isoäidistään. Juuri tässä mielessä säilössä olevat turkisvaatteet toimivat muistelun välineinä: ne ovat esineitä, jotka ylläpitävät muistoja, välittävät sekä muokkaavat niitä, ja joiden kanssa on hyvä kertoa. Muistelu kertoi murroksesta, sillä se alkoi siitä, miten muistelija muutti kotoaan asumaan vasta mentyään naimisiin miehensä kanssa. Tämä oli aikanaan poikkeuksellista: elettiin vielä aikoja, jolloin suurin osa Kolgujevin nenetseistä asui saaren tundralla, mutta isoäidin perhe oli jo muuttanut neuvostoaikoina rakennettuun Bugrinon asutuskeskukseen. Bugrinossa asuvat lapset eivät oppineet kodassa elämisen arkea, vaikka vanhemmat ja isovanhemmat olivatkin siihen kasvaneet. Tuolloin nuori isoäiti joutui miehensä kotakylään muuttaessaan opettelemaan suurimman osan arkisista toimista itse. Muistoihin kiinnittyi häpeää, mutta myös ylpeyttä. Tarkasteltuamme turkisten kirjailuja ja koristelua ulkopinnalta isoäiti käänsi takin nurinpäin: sisäpinnalta paljastui käsin neulottujen ommelten verkosto, joka tihentyi mosaiikkikuvioiden kohdalla. Verkosto auttoi kuvittelemaan, miten pitkään paanitsan tekemiseen saa kulumaan aikaa, mutta myös, miten kauan tasaisen kauniin ompelukäsialan oppiminen kestää.

Itse ommeltu ja isoäidin ompelemat paanitsat toimivat strategisina muistelun välineinä, mutta tämän lisäksi niistä avautui kokonainen menneisyyden maailma ja sukupolvien ketju. Sukupolvien ketjussa on naisia, joiden käsien kautta tieto ja taito työstää poron- ja muiden 
eläinten nahkaa, tehdä suonilankaa, leikata oikeanmallisia paloja turkiksista ja ommella niistä vaatteita ja vaatteisiin kuvioita, kulkee. Tämän kaiken isoäiti tuli kertoneeksi minulle, mutta samalla hän käytti hyväkseen koko tilannetta, johon osallistuivat paanitsat, niiden tekijöiden ja tekemisen muistelu ja kerronta sekä ulkopuolinen, nuori tutkija, kääntääkseen ulkopuolisten tekemät historiantulkinnat päälaelleen ja luodakseen niiden tilalle tai rinnalle toisen. Jos toki turkikset olivat malliltaan arkaaisia, niiden kantajat olivat eläneet maailmoissa, joissa heidät oli sukupolvi toisensa jälkeen asetettu tähän ajalliseen tilaan. Tämä taas oli tehty huolimatta siitä tai usein vaieten siitä, että arkaaisiksi tai perinteiseksi nimettyjen käytänteiden ja esineiden lisäksi he olivat osallistuneet sen yhteiskunnan toimintaan, joka kunakin aikana oli nimetty nykyiseksi.

Keskeistä paanitsojen tulkinnassa on niiden materiaalisuuteen kiinnittyvä merkityksenanto. Paanitsat eivät ole vain asioita tai esineitä, joista voidaan tulkita nenetsien menneisyyttä tai kulttuurin merkityksiä. Paanitsat ovat osa nenetsien nykypäivää ja menneisyyttä ja sellaisina ne osallistuvat menneisyyden tuottamiseen. Omaehtoisen historiantuottamisen näkökulmasta onkin selvää, että sekä asujen perinteisyys että niiden mahdollisuudet toimia muistelun välineinä ovat keskeisiä myös alkuperäiskansojen parissa. Ei ole tarpeen kiistää typologisia tulkintoja tai historiallis-vertailevia analyysejä, mutta sen sijaan on äärimmäisen tärkeää muistaa, että ne tarjoavat vain yhden, ulkopuolisen ja usein etäännyttävän historiallisen näkökulman pukineisiin. Tässä mielessä esineillä on edelleen toimintakenttänsä museokokoelmien ulkopuolella tai muunakin kuin "perinteisinä" tai "kansallispukuina". Olennaista on suhtautua esineisiin liittyvään toimintaan, puheeseen ja kirjoituksiin muunakin kuin kontekstina tai taustatietona: ne kaikki liittyvät toisiinsa ja luovat tämän päivän suhdetta menneisyyteen ja tulevaisuuteen.

\section{Lopuksi}

Tämä artikkeli keskittyi tarkastelemaan muistelun materiaalisuutta, monimediaisuutta sekä medioiden vuorovaikutusta ja tarjoumia omaehtoisen muistamisen ja historiantuottamisen kontekstissa kolmen tapausesimerkin kautta soveltaen uusmaterialismin teorioita. Lähtökohtanamme on ollut muistitietotutkimus, viime vuosikymmenten aikana folkloristiikassa käyty keskustelu vernakulaarin käsitteestä sekä omaehtoisen muistamisen ja historiantuottamisen tarkastelu aktiivisena toimintana, jolle on tyypillistä erilaisten resurssien hyödyntäminen. Olemme halunneet kiinnittää huomiota omaehtoisen (vernacular) muistelun moniin muotoihin ja medioihin, joiden välityksellä menneisyyksiä tuotetaan ja tulkitaan.

Artikkelissamme ehdotamme, että jos eri lähteiden yhdistely ja siitäkin seuraava moniaineksisuus luonnehtii vernakulaaria toimintaa, kuten Dorothy Noyes (2012) on todennut, medioiden vuorovaikutuksen tarkastelu avaa yhden varteenotettavan välineen omaehtoisen muistelun ja historiantuottamisen kuvaamiseen ja ymmärtämiseen. Sen avulla voidaan purkaa korkean ja matalan, objektiivisen ja subjektiivisen tai julkisen ja yksityisen välisiä vastakkainasetteluja. Juuri näiden vastakkainasettelujen purkaminen on tärkeää, jotta voidaan ymmärtää, että vernakulaari tai omaehtoinen muistaminen ei ole jotain itsessään, sellainen essentialistinen kokonaisuus, joka asettuisi hallitsevan historiantuottamisen vastakohdaksi. Purkamisen lisäksi merkityksellistä on ymmärtää, että vernakulaari toiminta ja käytänteet syntyvät ja elävät jatkuvassa vuorovaikutuksessa ja suhteessa virallisen tai hallitsevan kanssa: omaehtoinen historia pohjautuu niin julkisiin kuin yksityisiinkin menneisyydestä kertoviin lähteisiin, minkä lisäksi sen avulla voidaan kiistää, rikastaa tai ottaa haltuun 
julkista ja hallitsevaa menneisyyskuvaa. Jos omaehtoinen muistaminen ja sen luovat käytännöt ja oral history -tutkimus onkin toisinaan esitetty "hallitsevan" historiankirjoituksen vastapooleina, olemme tässä artikkelissa hahmottaneet nämä vastavuoroisiksi ja relationaalisiksi prosesseiksi.

Artikkelissamme tavoitteenamme oli myös monipuolistaa suomalaisen muistitietotutkimuksen edelleen voimakkaasti muistelun kielelliseen ja kerronnalliseen ulottuvuuden keskittyviä keskusteluja. Uusmaterialismin teorioita on toistaiseksi arvioitu vähänlaisesti suomalaisen muistitietotutkimuksen ja kansainvälisen oral history -tutkimuksen piirissä (ks. kuitenkin Kuusisto-Arponen ja Savolainen 2016). Myös kulttuurisen muistitutkimuksen piirissä uusmaterialismi on vasta nousemassa kiinnostuksen ja teoretisoinnin kohteeksi (ks. esim. Rigney 2017). Tämä ei kuitenkaan tarkoita sitä, etteikö materiaalisuutta olisi tutkittu tai haastattelumenetelmää hyödynnetty materiaalisuuden tutkimuksessa (esim. Peltonen 2003; Lukin 2010; Savolainen 2015; 2018; Frykman ja Povrzanović Frykman 2016; Heimo ja Salmi-Niklander 2019; Korjonen-Kuusipuro ja Kuusisto-Arponen 2017; Koskinen-Koivisto ja Thomas 2018). Ylipäätään materiaalisuuden kysymykset ovat aina olleet keskeisiä länsimaisessa filosofiassa. Uusmaterialismin uutuus liittyy pikemminkin vastakkainasettelujen purkamisen seurauksiin, siihen, ettei kielellisen merkityksenannon ja materian näkeminen toisistaan erillisinä ole perusteltua. Tapausesimerkeissä olemmekin halunneet havainnollistaa, että muistamista tapahtuu muutoinkin kuin kielellisissä käytänteissä. Olemme halunneet myös korostaa sitä, että tästä johtuen kielellisiä käytänteitä ei tule irrottaa niistä aineellisista tai visuaalisista medioista, jotka ovat osa muistamisen moninaisia prosesseja. Tapausesimerkkien avulla olemme tuoneet esiin, millaisia uudenlaisia näkökulmia muistamisen prosessuaalisuuteen ja relationaalisuuteen kielellisten, materiaalisten ja visuaalisten muistamisen medioiden vuorovaikutuksen tarkastelu avaa.

Ensimmäisessä tapausesimerkissämme lähestyttiin netissä tapahtuvan omaehtoisen muistamisen monimediaisuutta erittelemällä vuoden 1918 sisällissodan tapahtumien muistamisen erityispiirteitä. Siinä havainnollistettin, että omaehtoisessa muistamisessa on kyse useiden inhimillisten ja ei-inhimillisten toimijoiden sekä medioiden, kuten kuvan ja tekstin välisestä vuorovaikutuksesta, jonka Facebook on mahdollistanut uudella tavalla. Samaan aikaan ymmärryksemme yksityisen ja julkisen muistamisen suhteista ovat muuttuneet. Toisessa tapausesimerkissämme tarkasteltiin valokuvan tarjoumia materiaalisena ja esittävänä muistamisen mediana sekä analysoitiin valokuvien ja kerronnan vuorovaikutusta. Tapausesimerkissä tuotiin esiin, että Ojalan taiteessa valokuva on erityinen menneisyyttä materialisoiva ja esittävä media, minkä lisäksi sukuvalokuvat vaikuttavat maailmassa nimenomaan vuorovaikutuksessa toisten medioiden (kirjalliset kertomukset) ja toimijoiden (Ojala) kanssa. Medioiden vuorovaikutuksen ja tarjoumien analyysi osoittaa, että Ojalan muistaminen kytkeytyy yksityisen ja julkisen sekä yksilöllisen ja kollektiivisen välisen suhteen pohtimiseen ja rakentamiseen. Kolmas tapausesimerkkimme toi esiin, että akateemisessa tutkimuksessa on käytetty aineellista kulttuuria luomaan etäännyttäviä ja paikallisyhteisön omia historiantulkintoja ohittavia tai niistä vaikenevia historiantulkintoja. Samalla on rakennettu historiakuviin perustuva toiseuttava ja alistava hierarkia, jossa alkuperäiskansojen kulttuuri tai perinteinen kulttuuri kertoo menneisyydestä. Turkiksiaan esittelevä nainen tahtoi kiistää hierarkiat ja tuoda esiin yhtäältä omaa henkilökohtaista menneisyyttään mutta myös naisten ja sukupolvien historiaa, kun hän käytti nenetsien paanitsoja, niiden kuviointeja ja ompeleita muistamisen välineinä. Se, mitä oli tutkimuksissa käsitelty julkisena ja yleisellä tasolla muuntui muistelussa yksityiseksi. 
Kaikissa esimerkeissä materiaalinen, visuaalinen ja kerronnallinen toimivat muistamisen mahdollistajina, tekijöinä, jotka merkityksellistyvät suhteessa niihin inhimillisen ja ei-inhimillisen toiminnan verkostoihin, joiden osia ne ovat. Vaikka aineellista voidaan käyttää todistusaineistona, muistuttajana tai mielikuvituksen herättäjänä, sen merkitys rakentuu aina uudestaan niissä tilanteissa, joissa aineellinen yhdistetään menneisyyteen ja sitä kautta myös tulevaan. Merkityksellistä on, että muistaminen ja historiantuottaminen edellyttävät ja hyödyntävät erilaisia aineellisia medioita, joista kieli on vain yksi. Kielellisten ilmaisujen irrottaminen niistä materian virroista, joiden osa se on, on yksi kielen abstrahoinnin tapa, jonka avulla voidaan tarkastella verbaalista ilmaisua ikään kuin se tapahtuisi omassa merkitysavaruudessaan. Niin tutkijat kuin muistelijat hyödyntävät tätä kielellisen ilmaisun ominaisuutta toiminnassaan. Omaehtoiseen muistamiseen liittyy kuitenkin elimellisesti kielellisten ja ei-kielellisten aineellisuuksien, erilaisten medioiden vuorovaikutus ja yhdistely niiden tarjoumien mahdollistamissa puitteissa.

Uusmaterialismin näkökulma aiheuttaa radikaalin muutoksen tiedon tuottamisen lähtökohtiin. Se kyseenalaistaa muistitietotutkimuksen ihmis- ja kielikeskeisen lähestymistavan kääntämällä huomion siihen, että ihmiset ja heidän kertomuksensa ovat osa laajempaa materiaalisuuksien ja toimijoiden relationaalista verkostoa, jossa todellisuus muodostuu, eivät suinkaan ainoita tai ensisijaisia merkitysten luojia. Sen sijaan, että näkisimme toimijat ja mediat alisteisessa tai vastakkaisessa suhteessa toisiinsa - siten, että vain esimerkiksi kieli määrittäisi muistamisen merkitysten ja seurausten muodostumista esineiden, kuvien tai digitaalisen teknologian ollessa passiivisia kohteita tai kanavia - ne voidaan havaita toisiinsa kietoutuneiksi ja niiden merkitykset tämän relationaalisen suhteen tuotoksiksi. Näkökulman muutos pakottaa tarkastelemaan muistamista osana monien medioiden vuorovaikutteista verkostoa. Tämä on metodologinen haaste tutkijoille, minkä lisäksi materian toimijuuden huomioiminen antaa aiheen kysyä, mitä tarkalleen tarkoitamme, kun puhumme omaehtoisuudesta. Minkälaisilla ehdoilla muistaminen lopulta tapahtuu?

Tässä artikkelissa omaehtoisuutta on käytetty kuvaavana terminä, joka mahdollistaa myös analyyttisen erittelyn muistamisen ja historiantuottamisen kulttuuristen ja sosiaalisten muotojen välillä samaan tapaan kuin omakohtainen mahdollistaa perspektiivien ja skaalojen erittelyn. Kaikissa esimerkeissä hallitseviksi mielletyt tai omakohtaisia menneisyyksiä laajemmalle ulottuvat historiantulkinnat olivat läsnä, mutta ei yksiselitteisesti omaehtoisen tai omakohtaisen menneisyyskuvan rakentamisen vastakohtana tai siitä erillisenä. Tässä suhteessa voidaan huomata, että omaehtoisen tai omakohtaisen historian suhde hallitseviksi ja kollektiivisiksi miellettyihin historiantulkintoihin saattaa olla jännitteinen, jos hallitsevaksi ja kollektiiviseksi mielletty historiantulkinta tunnistetaan mutta sitä ei tunnusteta. Toisaalta omaehtoisen ja omakohtaisen historian käytänteissä tuotetaan myös paikallisia tai suku- ja henkilökohtaisia lisäkertomuksia, joiden voidaan ajatella istuvan hyvin tai rikastavan hallitseviksi ja kollektiivisiksi miellettyjä menneisyyskuvia. Se, mikä kulloinkin on hallitsevaa, omaehtoista, kollektiivista tai omakohtaista rakentuu jokaisessa muistamisen hetkessä, samoin kuin niiden välinen suhde.

Olennaista on myös havaita, että omaehtoisen muistamisen prosesseissa on läsnä muitakin merkittäviä suhteita kuin hallitsevan ja ei-hallitsevan, kollektiivisen ja omakohtaisen muistamisen vuoropuhelu. Erilaisten lähteiden, esittämisen tapojen ja muistamisen medioiden etsiminen ja yhdistely tuottavat omissa konteksteissaan huomiota herättäviä, koskettavia, todisteena toimivia ja yhteisön tai yksilön identiteetistä kertovia tai menneisyyden ja nykyisen 
suhdetta rakentavia kertomuksia. Tällaiset hybridit, paikalliset tai ylipaikalliset muistamisen ja merkityksenannon prosessit ohittavat omaehtoisen ja ei-omaehtoisen, omakohtaisen ja ei-omakohtaisen vastakkainasettelun tai asettuvat poikkiteloin sen kanssa. Niissä alistetaan aiemmat menneisyyden tulkinnat uusille, jolloin menneisyyskuvista aletaan keskustella toisilla areenoilla. Esimerkkitapauksiemme muistamisen areenat ovat siinä määrin toisistaan poikkeavia, että niiden avulla voidaan hahmottaa, miten erilaisen läsnäolon ja vuorovaikutuksen tunteen sosiaalinen media, kirjallinen esitys tai kenttätyötilanne tuottavat. Niiden kautta voidaan myös havaita, miten moninaisia ovat ne aineelliset muistamisen välineet ja miten loputtomiin materian ketjuihin ne ottavat merkityksellä tavalla osaa.

\section{Tutkimusaineistot}

Kenttäpäiväkirja. 2000. Karina Lukinin hallussa.

Ojala, Ella. 1988. Pitkä kotimatka. Helsinki: Tammi.

Ojala, Ella. 1990. Suomi näkyy. Helsinki: Tammi.

Ojala, Ella. 1991. Pelastunut albumi. Helsinki: Tammi.

Ojala, Ella. 1994. Ensimmäinen kevät. Helsinki: Tammi.

Facebook, Suomen sisällissota 1918. 29.12.2019

Why we post, Discoveries 7, https://www.ucl.ac.uk/drupal/site why-we-post/discoveries/7we-used-to-just-talk-now-we-talk-photos 29.12.2019

\section{Kirjallisuus}

Amelina, Maria Konstantinovna. 2014. "Nenetskaja ženskaja odežda pani: zapadnaja panitsa i vostotšnaja jaguška." Uralo-altajskie issledovanija 15(4): 7-31.

Anderson, David G. ja Dmitry V. Arzyutov. 2016. "The Construction of Soviet Ethnography and 'The Peoples of Siberia"'. History and Anthropology 27(2): 183-209. https://doi.org/ 10.1080/02757206.2016.1140159

Bastman, Eeva-Liisa, Kati Kallio ja Tuomas M. S. Lehtonen. 2020. Vernakulaarin monta tasoa. Näkökulmia Matthias Salamniuksen runoon Ilo-Laulu Jesuxesta. Elore 27(1). https:// doi.org/10.30666/elore.89057

Barad, Karen. 2007. Meeting the Universe Halfway: Quantum Physics and the Entanglement of Matter and Meaning. Durham: Duke University Press. https://doi. org/10.1215/9780822388128

Barthes, Roland. 1983. Camera Lucida: Reflections on Photography. New York: Hill and Wang.

Bell, Joshua. 2017. "A Bundle of Relations: Collections, Collecting, and Communities." Annual Review of Anthropology 46: 241-259. https://doi.org/10.1146/ annurev-anthro-102313-030259

Bennett, Jane. 2010. Vibrant Matter: A Political Ecology of Things. Durham: Duke University Press. https://doi.org/10.1215/9780822391623

Boyd, Doug ja Mary Larson. 2014. Oral History and Digital Humanities: Voice, Access, and Engagement.Basingstoke:PalgraveMacMillan.https://doi.org/10.1057/9781137322029 
Bruchac, Margaret M. 2018. "Broken Chains of Custody: Possessing, Dispossessing, and Repossessing Lost Wampum Belts." Proceedings of the American Philosophical Society 162(1): 56-105. https://www.amphilsoc.org/sites/default/files/2018-08/attachments/ Bruchac.pdf

Clifford, James. 1988. The Predicament of Culture: Twentieth-Century Ethnography, Literature, and Art. Cambridge (MA): Harvard University Press. https://doi.org/10.2307/j.ctvjf9x0h

Coole, Diana H. ja Samantha Frost. 2010. "Introducing the New Materialisms." Teoksessa New Materialisms: Ontology, Agency, and Politics, toimittaneet Diana H. Coole ja Samantha Frost, 1-43. Durham: Duke University Press. https://doi. org/10.1215/9780822392996-001

De Cesari, Chiara ja Ann Rigney, toim. 2014. "Introduction: Beyond methodological nationalism." Teoksessa Transnational Memory: Circulation, Articulation, Scales, toimittaneet Chiara De Cesari ja Ann Rigney, 1-25. Berlin: De Gruyter. https://doi. org/10.1515/9783110359107

van Dijck, José. 2007. Mediated Memories in the Digital Age. Standford: Standford University Press.

Dolphijn, Rick ja Iris van der Tuin. 2012. New Materialism: Interviews \& Cartographies. Ann Arbor: Open Humanities Press. https://doi.org/10.3998/ohp.11515701.0001.001

Erll, Astrid. 2008. "Cultural Memory Studies: an Introduction." Teoksessa Cultural Memory Studies: an International and Interdisciplinary Handbook, toimittaneet Astrid Erll, Astrid, Ansgar Nünning ja Sara Young, 1-15. Berlin, Berlin: De Gruyter. https://doi. org/10.1515/9783110207262

Erll, Astrid. 2011a. Memory in Culture. Basingstoke: Palgrave Macmillan. https://doi. org/10.1057/9780230321670

Erll, Astrid. 2011b: "Travelling Memory." Parallax 17(4): 4-18.https://doi.org/10.1080/1353 $\underline{4645.2011 .605570}$

Erll, Astrid ja Ann Rigney, toim. 2009. Mediation, Remediation, and the Dynamics of Cultural Memory. Berlin: De Gruyter.

Fabian, Johannes. 1983. Time and the Other: How Anthropology Makes its Object. New York: Columbia University Press.

Faulkner, Simon, Farida Vis ja Ransesco D'Orazio. 2017. "Analysing Social Media Images." The SAGE Handbook of Social Media, toimittaneet Jean Burgess, Alice E. Marwick ja Thomas Poell, 160-178. London: SAGE. https://doi.org/10.4135/9781473984066.n10

Fingerroos, Outi, Riina Haanpää, Anne Heimo, Anne ja Ulla-Maija Peltonen, toim. 2006. Muistitietotutkimus: Muistitiedon metodologisia kysymyksiä. Helsinki: Suomalaisen Kirjallisuuden Seura.

Freund, Alexander ja Alistair Thomson. 2011a. "Introduction: Oral History and Photography." Teoksessa Oral History and Photography, toimittaneet Alexander Freund ja Alistair Thomson, 1-23. Basingstoke: Palgrave Macmillan. https://doi. org/10.1057/9780230120099_1

Frykman, Jonas ja Maja Povrzanović Frykman, toim. 2016. Sensitive Objects: Affect and Material Culture. Lund: Nordic Academic Press. https://doi.org/10.21525/kriterium.6

Garde-Hansen, Joanna, Andrew Hoskins ja Anna Reading, toim. 2009. Save As... Digital Memories. Basingstoke: Palgrave Macmillan. https://doi.org/10.1057/9780230239418 
Gibbs, Martin, James Meese, Michael Arnold, Bjorn Nansen ja Marcus Carter. 2015. "\#Funeral and Instagram: death, social media, and platform vernacular." Information, Communication \& Society 18(3): 255-268. https://doi.org/10.1080/13691 18X.2014.987152

Hamilton, Paula ja Linda Shopes. 2008."Introduction: Building Partnerships between Oral History and Memory Studies."Teoksessa Oral history and public memories, toimittaneet Paula Hamilton ja Linda Shopes, vii-xvii. Philadelphia: Temple University Press.

Heimo, Anne. 2010a. Kapina Sammatissa. Vuoden 1918 paikalliset tulkinnat osana historian yhteiskunnallisen rakentamisen prosessia. Helsinki: Suomalaisen Kirjallisuuden Seura.

Heimo, Anne. 2010b."Kapina Sammatissa. Vuoden 1918 paikalliset tulkinnat osana historian yhteiskunnallisen rakentamisen prosessia. Lectio praecursoria Turun yliopistossa 8.5.2010." Elore 17(2): 138-143. https://doi.org/10.30666/elore.78881

Heimo, Anne. 2014. "The 1918 Finnish Civil War Revisited: The Digital Aftermath." Folklore 57: 141-168. https://doi.org/10.7592/FEJF2014.57.heimo

Heimo, Anne. 2016. "Nordic-Baltic oral history on the move." Oral History Journal 44(2), 37-46.

Heimo, Anne. 2017. "The Italian Hall Tragedy, 1913: A Hundred Years of Remediated Memories." Teoksessa The Twentieth Century in European Memory. Transcultural Mediation and Reception, toimittaneet Barbara Törnquist-Plewa ja Tea Sindbæk Andersen, 240-267. Leiden: Brill. https://doi.org/10.1163/9789004352353 012

Heimo, Anne ja Kirsti Salmi-Niklander. 2019. "Everyday reading cultures of Finnish immigrant communities", Participations: Journal of Audience and Reception Studies 16(1): 582-604. https://www.participations.org/Volume\%2016/Issue\%201/27.pdf

Hirsch, Marianne. 1997. Family Frames. Photography, Narrative, and Postmemory. Cambridge (MA): Harvard University Press.

Hirsch, Marianne ja Leo Spitzer. 2006. "Testimonial Objects: Memory, Gender, and Transmission." Poetics Today 27(2): 353-383. https://doi. org/10.1215/03335372-2005-008

Hodgkin, Katherine ja Susannah Radstone. 2003. "Introduction: Contested Pasts." Contested Pasts: the Politics of Memory, toimittaneet Katherine Hodgkin ja Susannah Radstone, 1-21. London: Routledge. https://doi.org/10.4324/9780203391471

Homitš, L. V. 1966. Nentsy: istoriko-etnografitšeskie otšerki. Leningrad: Nauka.

Howard, Robert Glenn. 2010. "The Vernacular Mode: Locating the Non-Institutional in the Practice of Citizenship." Teoksessa Public Modalities, toimittaneet Daniel C. Brouwer ja Robert Asen, 240-261. Tuscaloosa: University of Alabama Press.

Howard, Robert Glenn. 2008. "The Vernacular Web of Participatory Media." Critical Studies in Media Communication, 25(5): 490-513. https://doi.org/10.1080/15295030802468065

Ingold, Tim. 2012."Toward an Ecology of Materials." Annual Review of Anthropology 41:427442. https://doi.org/10.1146/annurev-anthro-081309-145920

Jenkins, Henry, Mizuko Ito ja danah boyd. 2016. Participatory Culture in a Networked Era: A Conversation on Youth, Learning, Commerce, and Politics. Cambridge, Malden (MA): Polity Press.

Kalela, Jorma. 2002. Historiantutkimus ja historia. Helsinki: Gaudeamus. 
Kalela, Jorma. 2012. Making History: The Historian and the Uses of the Past. Basingstoke: Palgrave Macmillan.

Kõresaar, Ene ja Kirsti Jõesalu. 2016. "Post-Soviet Memories and 'Memory Shifts' in Estonia." Oral History Journal 44(2): 47-58.

Keane, Webb. 2008. "The Evidence of the Senses and the Materiality of Religion." Journal of the Royal Anthropological Institute 14: 110-127. https://doi. org/10.1111/j.1467-9655.2008.00496.x

Keane, Webb. 2015. Ethical Life: Its Natural and Social Histories. Princeton and Oxford: Princeton University Press. https://doi.org/10.23943/princeton/9780691167732.001.0001

Keane, Webb. 2018. "On Semiotic Ideology." Signs and Society 6(1): 64-87. https://doi. org/10.1086/695387

Korjonen-Kuusipuro, Kristiina ja Anna-Kaisa Kuusisto-Arponen. 2017. "Muistelun monet muodot: Kertomus, kehollisuus ja hiljaisuus paikan tietämisen tapoina." Elore 24(1): 1-17. https://doi.org/10.30666/elore.79278

Koski, Kaarina. 2011. "Mediakulttuurin murros, YouTube ja folklore." Elore 18(1): 14-27. https://doi.org/10.30666/elore.78918

Koski, Kaarina ja Riikka Turtiainen. 2020. "Vernakulaari digitaalisissa ympäristöissä." Elore 27(1). https://doi.org/10.30666/elore.88834

Koskinen-Koivisto, Eerika ja Suzie Thomas. 2018. "Remembering and Forgetting, Discovering and Cherishing: Engagements with material culture of war in Finnish Lapland." Ethnologia Fennica 45: 28-54. https://doi.org/10.23991/ef.v45i0.60647

Kosonen, Miia, Salla-Maaria Laaksonen, Anja Terkamo-Moisio ja Henrik Rydenfelt. 2018. "Sosiaalinen media ja tutkijan etiikka." Etiikka.fi. Luettu 9.1.2020. https://doi. org/10.23983/mv.69924

Kuusisto-Arponen, Anna-Kaisa ja Ulla Savolainen. 2016. "The Interplay of Memory and Matter: Narratives of Former Finnish Karelian Child Evacuees." Oral History Journal 44(2): 59-68.

Langford, Martha. 2001. Suspended Conversations: The Afterlife of Memory in Photographic Albums. Montreal: McGill-Queen's University Press.

Latour, Bruno. 2005. Reassembling the Social: An Introduction to Actor-Network-Theory. Oxford: Oxford University Press.

Latvala, Pauliina. 2005. Katse menneisyyteen: Folkloristinen tutkimus suvun muistitiedosta. Helsinki: Suomalaisen Kirjallisuuden Seura.

Lehtonen, Mikko. 2014. Maa-ilma: materialistisen kulttuuriteorian lähtökohtia. Tampere: Vastapaino.

Lukin, Karina. 2010. "Animating the Unseen: Landscape Discourses as Mnemonics among Kolguyev Nenets." Suomen antropologi. Journal of the Finnish Anthropological Society 35(1): 23-42.

Löfgren, Orvar. 1997. "Scenes from a Troubled Marriage: Swedish Ethnology and Material Culture Studies." Journal of Material Culture 2(1): 95-113. https://doi. org/10.1177/135918359700200105 
Löfgren, Orvar. 2012. "Material Culture." Teoksessa A Companion to Folklore, toimittaneet Galit Hasan-Rokem ja Regina Bendix, 169-183. Malden (MA): Blackwell. https://doi. org/10.1002/9781118379936.ch9

Noyes, Dorothy. 2012. "The Social Base of Folklore." Teoksessa A Companion to Folklore, toimittaneet Galit Hasan-Rokem ja Regina Bendix, 13-39. Malden (MA): Blackwell. https://doi.org/10.1002/9781118379936.ch1

Noyes, Dorothy. 2016. Humble Theory: Folklore's Grasp on Social Life. Bloomington: Indiana University Press. https://doi.org/10.2307/j.ctt1zxzObs

Olin-Arvola, Kaija. 2008. Ida Matilda Lindell - Arjen Sankari. Luettu 29.12.2019. https:// web.archive.org/web/20160819093719/http://cenmagazin.com/Historia/lda\%20 Matilda\%20Lindell.pdf.

Paasonen, Susanna. 2013. "Ihmisiä, kuvia ja tekstejä." Teoksessa Otteita verkosta: Verkon ja sosiaalisen median tutkimusmenetelmät, toimittaneet Salla Laaksonen, Janne Matikainen ja Minttu Tikka, 34-48. Tampere: Vastapaino.

Peltonen, Ulla-Maija. 1996. Punakapinan muistot: tutkimus työväen muistelukerronnan muotoutumisesta vuoden 1918 jälkeen. Helsinki: Suomalaisen Kirjallisuuden Seura.

Peltonen, Ulla-Maija. 2003. Muistin paikat: vuoden 1918 sisällissodan muistamisesta ja unohtamisesta. Helsinki: Suomalaisen Kirjallisuuden Seura.

Peltonen, Ulla-Maija. 2006. "Muistitieto folkloristiikassa." Teoksessa Muistitietotutkimus. Metodologisia kysymyksiä, toimittaneet Outi Fingerroos, Riina Haanpää, Anne Heimo ja Ulla-Maija Peltonen, 93-119. Helsinki: Suomalaisen Kirjallisuuden Seura.

Primiano, Leonard Norman. 1995. "Vernacular Religion and the Search for Method in Religious Folklife." Western Folklore 54: 37-56. https://doi.org/10.2307/1499910

Prytkova, N. F. 1970. "Odežda narodov samodijskoj gruppy kak istoritšeskij istotšnik." Teoksessa Odežda narodov Sibiri. Sbornik statej muzeja antropologii i etnografii, toimittanut S. V. Ivanov, 3-99. Leningrad: Nauka.

Rigney, Ann. 2017. "Materiality and Memory: Objects to Ecologies. A Response to Maria Zirra." Parallax 23(4): 474-478. https://doi.org/10.1080/13534645.2017.1374517

Rigney, Ann. 2018. "Remembrance as Remaking: Memories of the Nation Revisited." Nations and Nationalism 24(2): 240-257. https://doi.org/10.1111/nana.12388

Rosenzweig, Roy ja David Thelen. 1998: Presence of the Past: Popular Uses of History in American Life. New York, Chichester: Columbia University Press.

Savolainen, Ulla. 2015. Muisteltu ja kirjoitettu evakkomatka: Tutkimus evakkolapsuuden muistelukerronnan poetiikasta. Joensuu: Suomen Kansantietouden Tutkijain Seura.

Savolainen, Ulla. 2017. "Tellability, Frame and Silence: The Emergence of Internment Memory." Narrative Inquiry 27(1): 24-46. https://doi.org/10.1075/ni.27.1.02sav

Savolainen, Ulla. 2018. "Points and Poetics of Memory: (Retrospective) Justice in Oral History Interviews of Former Internees." Memory Studies (published Online first 22 Oct. 2018). https://doi.org/10.1177/1750698018806946

Sontag, Susan. 1977. On Photography. New York: Farrar, Straus and Giroux.

Srigley, Katrina ja Stacey Zembrzycki. 2009. "Remembering Family, Analyzing Home: Oral History and the Family." Oral History Forum d'histoire orale 29: 1-29. Luettu 9.1.2020. http://www.oralhistoryforum.ca/index.php/ohf/article/view/243/293 
Summerfield, Penny. 2019. Histories of the Self. Personal Narratives and Historical Practice. Abingdon, Oxon: Routledge. https://doi.org/10.4324/9780429487217

Suominen, Jaakko. 2009. "Johdannoksi: Netin kulttuurihistoriaa." Teoksessa Funetista Facebookiin:Internetin kulttuurihistoria, toimittaneet Petri Saarikoski, Jaakko Suominen, Riikka Turtiainen ja Sari Östman, 7-22. Helsinki: Gaudeamus.

Thomson, Alistair. 2007."Four Paradigm Transformations in Oral History." Oral History Review 34(1): 49-70. https://doi.org/10.1525/ohr.2007.34.1.49

Torsti, Pilvi. 2012. Suomalaiset ja historia. Helsinki: Gaudeamus.

Turtiainen Riikka ja Sari Östman. 2009. "Tavistaidetta ja verkkoviihdettä: Omaehtoisten verkkosisältöjen tutkimusetiikkaa." Teoksessa Kulttuurituotanto: kehykset, käytäntö ja prosessit, toimittaneet Maarit Grahn ja Maunu Häyrynen, 336-358. Helsinki: Suomalaisen Kirjallisuuden Seura.

Turtiainen, Riikka ja Sari Östman. 2013. "Verkkotutkimuksen eettiset haasteet: Armi ja anoreksia."Teoksessa Otteita verkosta. Verkon ja sosiaalisen median tutkimusmenetelmät, toimittaneet Salla-Maaria Laaksonen, Janne Matikainen ja Minttu Tikka, 47-65. Tampere: Vastapaino.

Ukkonen, Taina. 2000. Menneisyyden tulkinta kertomalla. Muistelupuhe oman historian ja kokemuskertomusten tuottamisprosessina. Helsinki: Suomalaisen Kirjallisuuden Seura.

Ulla Savolainen (https://researchportal.helsinki.fi/en/persons/ulla-savolainen) on folkloristiikan dosentti. Hän työskentelee Suomen Akatemian tutkijatohtorina Helsingin yliopistossa. Hän tutkii inkeriläisten kokemuksiin kytkeytyvää kirjallisuutta sekä johtaa inkeriläisten muistikulttuureja tarkastelevaa tutkimushanketta.

Karina Lukin on folkloristiikan dosentti Helsingin yliopistossa. Hän työskentelee Itä-Suomen yliopiston Karjalan tutkimuslaitoksessa ja tutkii nenetsien suullista ja kirjallista ilmaisua sekä näiden tutkimushistoriaa.

Dosentti Anne Heimo toimii folkloristiikan ma. professorina Turun yliopiston historian, kulttuurin ja taiteiden tutkimuksen laitoksella. Hän tutkii omaehtoisen historian tuottamista ja jokapäiväisiä muistelukäytäntöjä netissä ja sen ulkopuolella. 